
Ophthalmic
Research
Ophthalmic Res 2010;44:205-224

DOI: $\underline{10.1159 / 000316695}$
Received: August 17, 2009

Accepted after revision: October 5, 2009

Published online: August 10, 2010

\title{
Retinal and Ocular Toxicity in Ocular Application of Drugs and Chemicals - Part II: Retinal Toxicity of Current and New Drugs
}

\author{
Fernando Marcondes Penha Eduardo B. Rodrigues Maurício Maia \\ Bruno A. Furlani Caio Regatieri Gustavo B. Melo Octaviano Magalhães, Jr. \\ Roberta Manzano Michel E. Farah
}

Vision Institute, Department of Ophthalmology, Federal University of São Paulo, São Paulo, Brazil

\section{Key Words}

Avastin · Lucentis · Retina $\cdot$ Bevacizumab $\cdot$ Ranibizumab ·

Monoclonal antibodies - Tumor necrosis factor •

Vascular endothelial growth factor $\cdot$ Corticosteroids .

Antimetabolites $\cdot$ Triamcinolone $\cdot$ Nonsteroidal

anti-inflammatory drugs $\cdot$ Microplasmin

\begin{abstract}
Aims: Retinal pharmacotherapy has gained great importance for the treatment of various retinal diseases. An increasing number of drugs have been constantly released into the market, especially for wet age-related macular disease and diabetic macular edema. In this review, the issues concerning the toxicity of current and new classes of drugs are discussed. Methods: An extensive search of the literature was performed to review various aspects of drug toxicity in retinal pharmacotherapy. The different major classes of drugs, such as corticosteroids, antibiotics, antimetabolites, antineoplastic agents, monoclonal antibodies (mAbs), nonsteroidal anti-inflammatory drugs, enzymes, fibrinolytics, miscellaneous anti-inflammatory and antiangiogenic agents, as well as toxicity unrelated to the drug were identi-
\end{abstract}

fied and discussed. Results: Corticosteroids like fluocinolone, dexamethasone or triamcinolone at low dose cause little damage to the retina, but at high doses signs of toxicity have been well documented. Complications like cataract and glaucoma are quite common with corticosteroids. Aminoglycosides showed differences in the type and doses associated with toxic reactions, thereby the following order of toxicity can be described (from most toxic to least toxic): gentamicin $>$ netilmicin $=$ tobramycin $>$ amikacin $=$ kanamycin. Vancomycin at the usual dose of $1 \mathrm{mg}$ is not toxic to the retina, while further studies are necessary in order to clarify the safety of new-generation quinolones. 5-Fluorouracil has been shown to be nontoxic to the retina after an injection of $2.5 \mathrm{mg}$ in animals. mAbs like ranibizumab and bevacizumab were demonstrated to be safe to the retina in cell culture, animals and humans at high doses. The exact biocompatibility of nonsteroidal anti-inflammatory agents like diclofenac needs further evaluation. Preservatives like benzyl alcohol and changes in $\mathrm{pH}$ or osmolarity exert an influence on the toxic effects of intravitreally applied drugs. Conclusions: A great number of drugs are now used mainly intravitreally without relevant retinal toxicity.

Copyright $\odot 2010$ S. Karger AG, Basel

\section{KARGER}

Fax +41 613061234 E-Mail karger@karger.ch www.karger.com
(C) 2010 S. Karger AG, Basel

0030-3747/10/0444-0205\$26.00/0

Accessible online at:

www.karger.com/ore
Fernando Marcondes Penha, MD, PhD

Emílio Fernandes Schoroeder, 111

Florianopolis, SC 88025-080 (Brazil)

E-Mail penhaepm@yahoo.com.br 


\section{Introduction}

Local ocular delivery of drugs has become a frequent and important technique for the treatment of retinal diseases [1-3]. Intravitreal injections have been applied widely for a variety of retinal diseases, including inflammatory, neovascular and edematous conditions of the macula, retina and vitreous [4-7].

The first report of intravitreal injection as a therapeutic modality was to administer air for the repair of rhegmatogenous retinal detachment [8]. However, later in the 1970s, intravitreal injections arose again as a common approach in the therapy of sight-threatening endophthalmitis, with aminoglycosides and cephalosporins. In 1987, the first case report described the benefit of delivery of ganciclovir sodium to a patient with cytomegalovirus (CMV) retinitis secondary to acquired immunodeficiency syndrome (AIDS) [9]. Later, in 1998 fomivirsen sodium (Vitravene ${ }^{\mathrm{TM}}$ ) was approved by the US Food and Drug Administration (FDA) for intravitreal injection in the treatment of CMV retinitis. Further studies were performed in the 1980s and 1990s of intravitreal administration of 5-fluorouracil (5-FU) for patients with proliferative vitreous retinopathy (PVR), dexamethasone for diabetic retinopathy after vitrectomy, and tissue plasminogen activator for the management of submacular hemorrhage $[10,11]$. Over the past two decades, numerous drugs have been developed for the treatment of different retinal and choroidal diseases. Triamcinolone acetonide (TA) has been widely used for the treatment of different edematous retinal diseases, such as diabetic macular edema and choroidal neovascular membranes. Recently, monoclonal antibodies (mAbs) emerged as the first therapeutic option with gain lines in visual acuity for choroidal neovascularization associated with age-related macular disease, with off-label bevacizumab and FDAapproved ranibizumab.

In this review, the safety issue of major classes of drugs applied or with potential use in retinal disease will be discussed. Additionally, biocompatibility issues regarding several drugs that may be potentially exploited to treat diseases of the back of the eye are presented. The issues surrounding the toxicity after systemic delivery to the posterior segment will not be discussed in this work.

\section{Major Classes of Drugs and Their Safety Profile after Local Ocular Application for Retinal Therapy}

\section{Corticosteroids}

Corticosteroids are powerful drugs widely used in ophthalmology, including the therapy of retinal diseases. In the past two decades, much research has been conducted to evaluate the indications of various types of steroids for vitreoretinal diseases. However, beyond the efficacy, one of the most important issues for the application of corticosteroids is to define the limitation of their side effects.

Fluocinolone acetonide is a synthetic corticosteroid with low solubility in aqueous solution. Experiments in rabbits provided the preclinical toxicity profile of fluocinolone with regard to the retina. Clinical examination, electroretinography or histological examination determined the safety of both 2 and $15 \mathrm{mg}$ synthetic fluocinolone acetonide in a preclinical study by Jaffe et al. [12]. Neither electroretinographic (ERG) alterations nor histology abnormalities were observed in their in vivo investigation. However, further clinical experience with implants containing 2 or $6 \mathrm{mg}$ of fluocinolone acetonide for therapy of uveitis revealed that a considerable number of patients experienced complications, which included glaucoma, cataract and retinal vein occlusion [13]

Dexamethasone belongs to the synthetic glucocorticoid class of steroid hormones with potent anti-inflammatory and immunosuppressant activities. Kwak and D'Amico [14] evaluated the retinal toxicity of doses ranging from 440 to $4,000 \mu \mathrm{g}$ dexamethasone in rabbit eyes and observed that with the $440-\mu \mathrm{g}$ dose, only a transient increase in staining of the Müller cells was observed, which normalized after 2 days. Recent research in cell culture accorded with the previous works, as a higher dose of $800 \mu \mathrm{g}$ dexamethasone was found to cause a reduction in the number of retinal cells. These experimental studies provided the basis for the safety profile of dexamethasone in humans, but future studies need to determine which dose, 400 or $800 \mu \mathrm{g}$, is safer in the treatment of edematous, proliferative and neovascular retinal diseases.

The first commercially available TA was Kenalog 40 (Bristol-Myers Squibb, Princeton, N.J., USA), an injectable suspension of TA for intramuscular or intra-articular use only, not recommended for intravenous or intraocular use. However, a series of contradicting studies have recently been published regarding retinal toxicity after intravitreal TA injection. On the one hand, various experiments with intravitreal injection of $4,16,20$ or 
$30 \mathrm{mg}$ TA resulted in normal histological and ERG retinal findings after 7 months. On the other hand, in one investigation the authors injected escalating doses from 0.5 to $20 \mathrm{mg}$ of suspended preservative-free TA into rabbits and found, at doses of $4 \mathrm{mg}$ or higher, prominent retinal damage manifested by damage to the photoreceptor outer segments and retinal pigment epithelium (RPE) [15]. Only few studies have addressed thus far the subretinal toxicity of TA, which could occur accidentally after macular hole surgery. One investigation tested a subretinal injection of $3 \mathrm{mg} / \mathrm{ml}$ TA in primate eyes and described neither ultrastructural nor cellular retinal damage [16]. However, Maia et al. [17] disclosed in a morphological study disturbance to photoreceptor segments after subretinal injection of preservative-free TA (Ophthalmos, São Paulo, Brazil), although no clinical abnormality on funduscopy or angiography was observed. These contrasting findings suggest that other factors may contribute to intravitreal retinal toxicity of TA, such as preservatives that will be discussed in a later section in this paper (fig. 1).

The clinical experience in recent years unraveled the risks to patients injected with intravitreal or periocular TA. The two most frequent complications are cataract and glaucoma, which occur in approximately 40 and 30\% of cases, respectively [17]. Most patients with cataract may be managed with surgery; however, glaucoma can be treated with eyedrops, and surgical procedures may be required in only around $1 \%$ of eyes [17]. Less common complications are endophthalmitis and pseudoendophthalmitis, encountered in around $0.5 \%$ of patients [17]. Recently, 2 new TA injectable suspensions, specifically produced and FDA approved for intraocular use, were launched on the market: Triesence (Alcon Inc., Fort Worth, Tex., USA) and Trivaris (Allergan Inc., Irvine, Calif., USA). Triesence is a $40-\mathrm{mg} / \mathrm{ml}$ preservative-free TA solution, and Trivaris is an $80-\mathrm{mg} / \mathrm{ml}$ drug solution, available in a dose of $4 \mathrm{mg}$ in a volume of $50 \mu \mathrm{l}$. Triesence was evaluated clinically for visualization during pars plana vitrectomy. This phase III, observer-masked study was conducted in 6 centers by 10 surgeons, involving 60 enrolled patients undergoing pars plana vitrectomy, where up to $4 \mathrm{mg}$ was administered to enhance visualization of vitreous and membranes. Triesence was well tolerated and effectively enhanced visualization of posterior segment structures during pars plana vitrectomy without any safety issues [18]. Moshfeghi et al. [19] conducted an interesting study comparing the crystal size of 3 different TA preparations: Kenalog 40 (Bristol-Myers Squibb), compounded preservative-free TA (PFTA, New England
Compounding Center, Framingham, Mass., USA) and Triesence (Alcon Inc.). In vitro, PFTA had more aggregates of smaller size than either TA or Triesence. In contrast, Triesence had a much larger aggregate size than both PFTA and TA, and this increased over time. These findings correlate with the clinical observations that PFTA and TA tend to disperse throughout the vitreous, whereas Triesence tends to conglomerate and gravitate toward the lowest portion of the eye in a globular form [19].

\section{Antibiotics}

The current application of antibiotics in retinal therapy refers to infectious endophthalmitis and uveitis. Postoperative endophthalmitis following cataract surgery is the main indication of intravitreal injection of antibiotics, even though in many cases there is no known microorganism responsible for the infection. Another important indication is posterior segment viral uveitis which is usually treated with systemic or intravitreal injections of acyclovir, valacyclovir and ganciclovir. Every intravitreally injected antibiotic drug could potentially lead to retinal toxicity, which will be addressed in further detail with consideration of the clinically safe dose (table 1).

\section{Aminoglycosides}

Amikacin used to be one of the most commonly used agents in the treatment of endophthalmitis in the past. Nowadays, it is well known that the aminoglycosides may pose a high risk of toxic effects to the retina. In vitro studies with isolated retinas showed that the b-wave in electroretinography is reduced in amplitude in the presence of low-dose $(1 \mathrm{mg} / \mathrm{ml})$ and completely eliminated by high-dose gentamicin $(10 \mathrm{mg} / \mathrm{ml})$ [20]. In in vivo ERG studies in animals, intraocular administration of gentamicin eliminated the $b$-wave and reduced the c-wave amplitude [20]. Histopathological evaluation demonstrated diffuse disruption of the nerve fiber layer and the inner plexiform layers in eyes exposed to this aminoglycoside antibiotic [20].

Regarding amikacin, an animal study disclosed retinal toxicity manifested by macrophages in the subretinal space, disorganization of the outer segments and RPE, and discontinuities in Bruch's membrane after repeated intravitreal injection of $400 \mu \mathrm{g}$ of amikacin [21]. D'Amico et al. [22] performed a comparative toxicity study of the aminoglycoside antibiotics (tobramycin, amikacin, netilmicin and kanamycin) after intravitreal injection into rabbits with doses ranging from 100 to $3,000 \mu \mathrm{g}$. The earliest manifestations of toxicity were confined to 

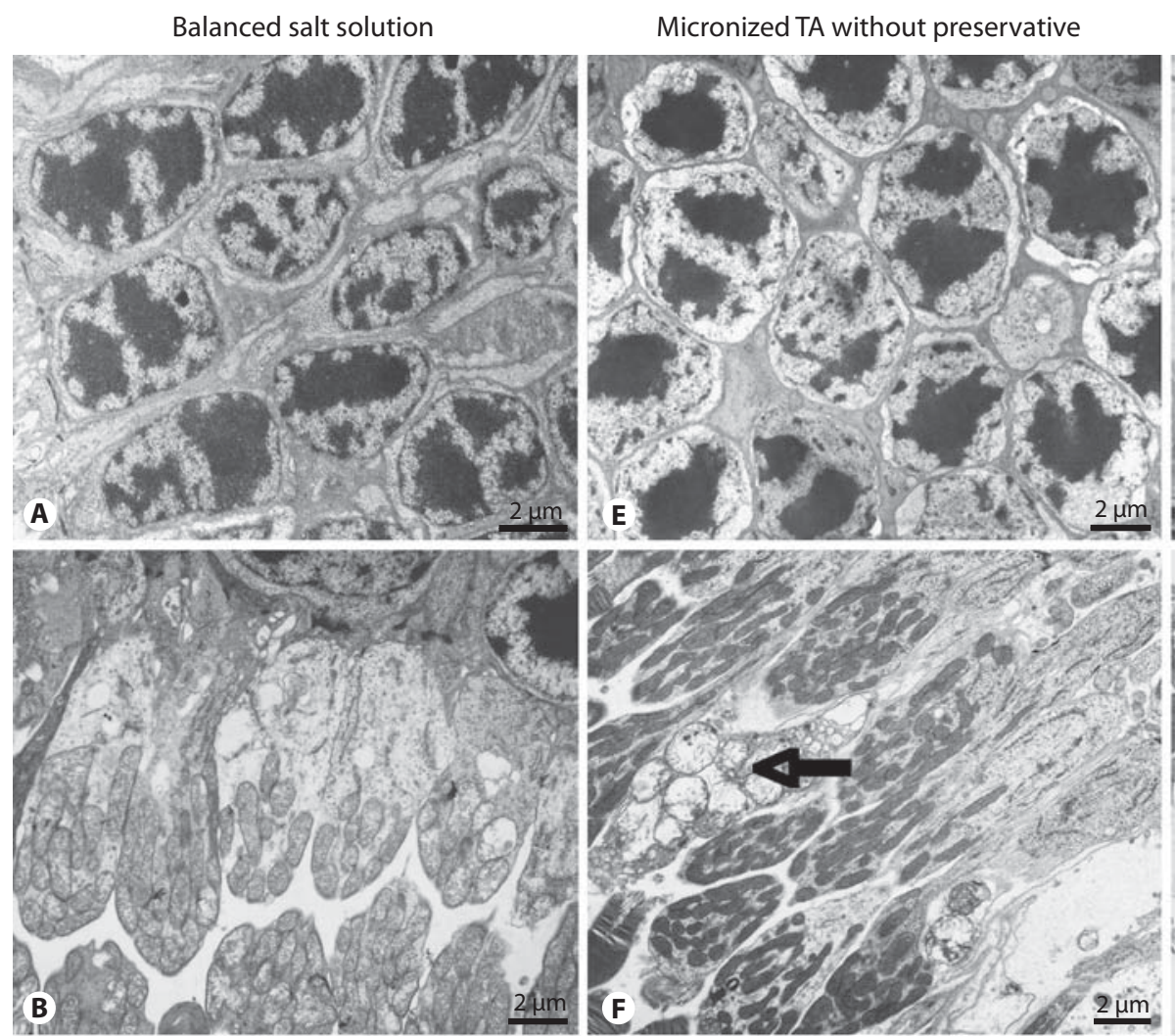

\section{Supernatant of TA with preservative}
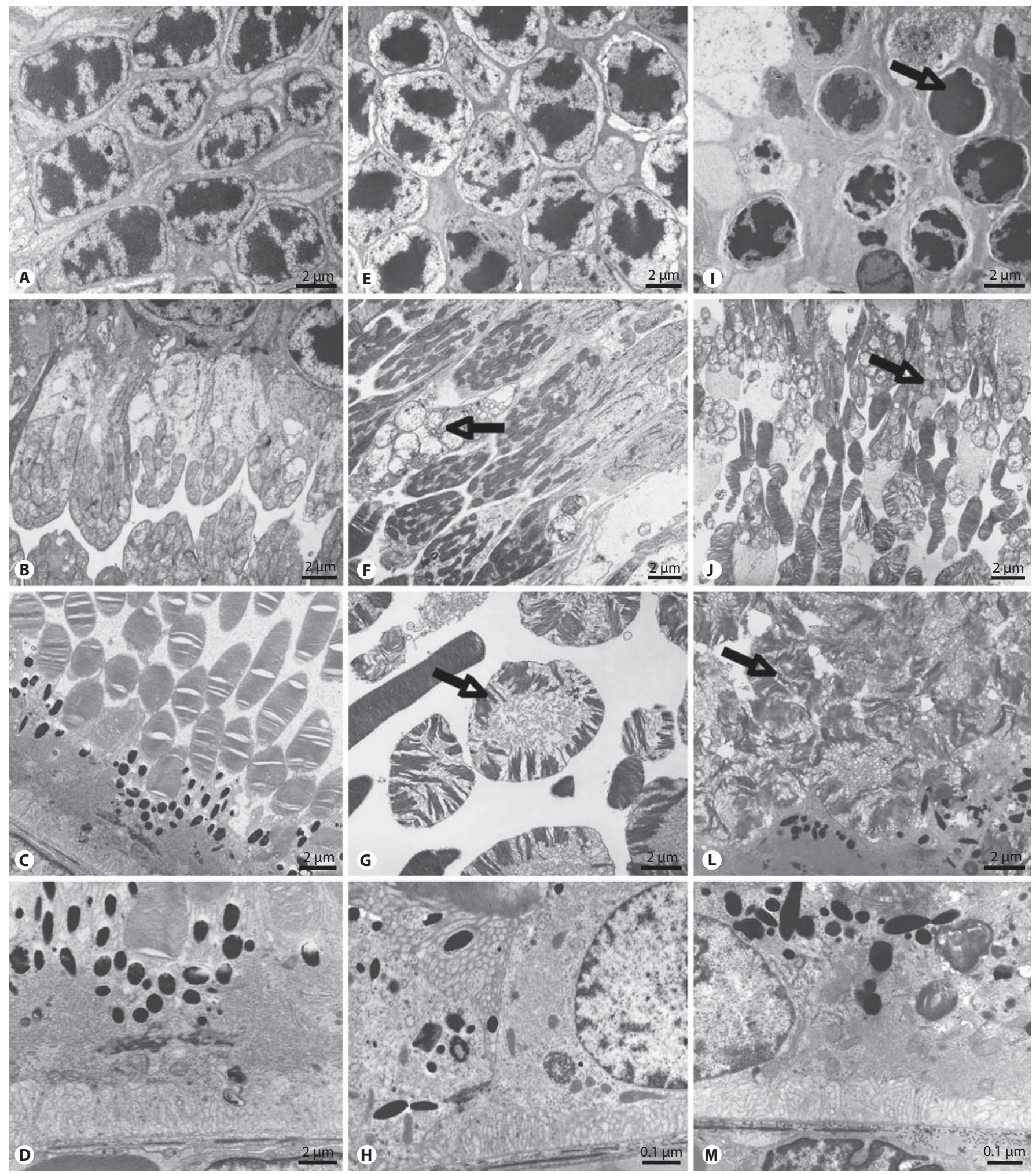

Fig. 1. After subretinal injection of preservative-free TA, the preservative, and control, different types of retinal cells manifest various signs of damage. The damage induced by the preservative (I-M) is more severe to neuroretinal posterior cells than that caused by the drug itself (E-H) and balanced salt solution (A-D). (Reprinted form Maia et al., 2008.) 
Fig. 2. A Color fundus picture showing extensive damage of neurosensorial retina and its vasculature as well as whitening and hemorrhages of the posterior pole after intravitreous injection of gentamicin. B Fluorescein angiography demonstrating signs of vasculities, vascular occlusion, and capillary non-perfusion after intravitreous injection of gentamicin (courtesy of Dr. Harry Flynn).
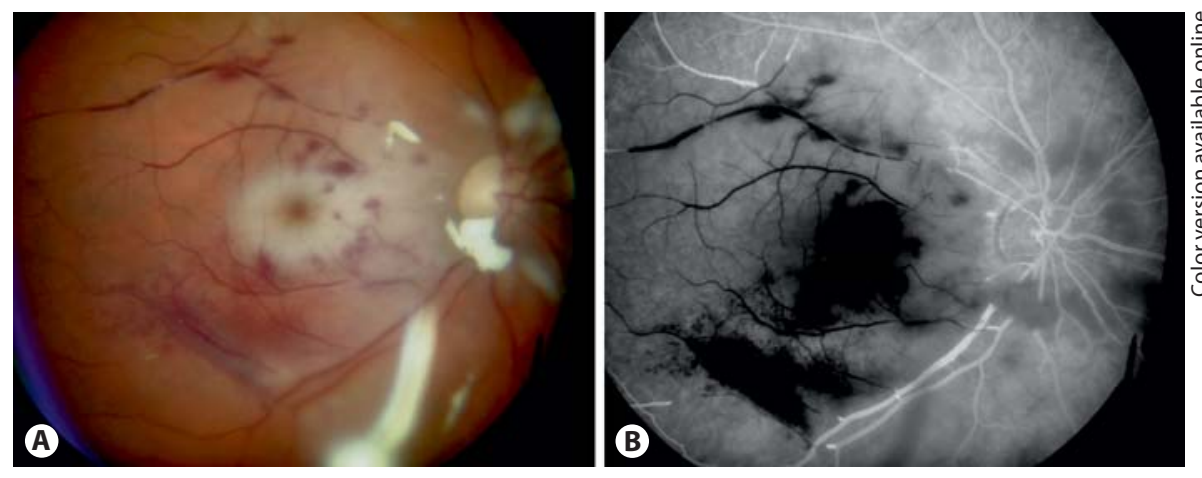

Table 1. Safe doses for various ophthalmic uses of antibiotics

\begin{tabular}{lccc}
\hline Drug & Topical & Subconjunctival & Intravitreal \\
\hline Amikacin & $10 \mathrm{mg} / \mathrm{ml}$ & $25 \mathrm{mg}$ & $400 \mu \mathrm{g}$ \\
Cefazolin & $50 \mathrm{mg} / \mathrm{ml}$ & $100 \mathrm{mg}$ & $2,250 \mu \mathrm{g}$ \\
Ceftazidime & $50 \mathrm{mg} / \mathrm{ml}$ & $100 \mathrm{mg}$ & $2,000 \mu \mathrm{g}$ \\
Ceftriaxone & $50 \mathrm{mg} / \mathrm{ml}$ & - & - \\
Clindamycin & $50 \mathrm{mg} / \mathrm{ml}$ & $15-50 \mathrm{mg}$ & $1,000 \mu \mathrm{g}$ \\
Gentamicin & $8-15 \mathrm{mg} / \mathrm{ml}$ & $10-20 \mathrm{mg}$ & $100-200 \mu \mathrm{g}$ \\
Imipenem & $5 \mathrm{mg} / \mathrm{ml}$ & - & - \\
Penicillin G & $100,000 \mathrm{units} / \mathrm{ml}$ & $0.5-1 \times 10^{6}$ units & 300 units \\
Piperacillin & $12.5 \mathrm{ng} / \mathrm{ml}$ & $100 \mathrm{mg}$ & - \\
Tobramycin & $8-15 \mathrm{mg} / \mathrm{ml}$ & $10-20 \mathrm{mg}$ & - \\
Vancomycin & $20-25 \mathrm{mg} / \mathrm{ml}$ & $25 \mathrm{mg}$ & $1,000 \mu \mathrm{g}$ \\
\hline
\end{tabular}

the outer retina with each drug, with lamellar lysosomal inclusions in the retinal pigment epithelium as the earliest finding. However, the aminoglycosides displayed marked differences in the threshold dose required to produce toxic reactions, permitting the following order of toxicity (from most toxic to least toxic): gentamicin $>$ netilmicin $=$ tobramycin $>$ amikacin $=$ kanamycin [22]

Further experience demonstrated that repetitive injections in nonvitrectomized eyes may result in increasing retinal toxicity. Later on, many cases of macular infarction after intravitreal injection of aminoglycosides such as amikacin have been reported in humans [23]. An accidental intravitreal injection of gentamicin could also promote macular infarction (fig. 2). This has led ophthalmologists to search for other Gram-negative targeting antibiotics for routine intravitreal injections.

\section{Cephalosporins}

Ceftazidime, a third-generation cephalosporin emerged as a good alternative to aminoglycosides for the treatment of endophthalmitis. An in vivo animal study with monkeys showed no toxicity at the commonly used concentration of $2.25 \mathrm{mg}$ ceftazidime, but others showed that ceftazidime may not be toxic in vitrectomized rabbit eyes [24]. However, it appears that cephalosporin may cause some degree of toxicity at otherwise nontoxic concentrations in a silicone-filled eye. Based on these preliminary data, surgeons have applied ceftazidime intravitreally in doses up to $2.25 \mathrm{mg}$ for the treatment of endophthalmitis.

\section{Vancomycin}

Vancomycin remains the antibiotic of choice, targeting highly pathogenic Gram-positive microorganisms, usually applied to patients intravitreally at a dose of $1 \mathrm{mg}$ in $0.1 \mathrm{ml}$. In vivo animal studies have shown no toxic effect of this antibiotic when used in an infusion solution that was given intraocularly after or during vitrectomy in rabbits [25]. However, in a silicone-filled eye, nontoxic concentrations of vancomycin may cause toxicity; there- 
fore, vitreous status should be evaluated when vancomycin is the antibiotic of choice as well $[26,27]$. In clinical practice, vancomycin has been associated with postoperative cystoid macular edema when infused as intracameral injection for prophylaxis during cataract surgery.

\section{Quinolones}

The ocular toxicity of another class of antibiotics, the quinolones, has been investigated in the recent past specifically for antibiotic prophylaxis in ocular surgery. Regarding intravitreal use, ciprofloxacin has not been associated with toxicity at the therapeutic levels of 100-500 $\mu \mathrm{g}$ in rabbits, and significant retinal damage has been observed only at $2 \mathrm{mg}$ [28].

The fourth-generation quinolones, which include moxifloxacin and gatifloxacin, have recently been shown to be useful for clinical use. An in vitro study showed that at concentrations higher than $160 \mu \mathrm{g} / \mathrm{ml}$, moxifloxacin induced adverse effects on primary RPE and neuronal retinal cells with regard to cell proliferation and cell viability [29]. Further studies in vivo showed that intravitreal injection of moxifloxacin did not cause retinal toxicity up to $100 \mu \mathrm{g} / \mathrm{ml}$ in mice or $150 \mu \mathrm{g}$ in rabbits [30]. In vivo, intravitreal injection of the other quinolone, gatifloxacin, at doses varying from 50 to $400 \mu \mathrm{g}$, caused no retinal toxicity, assessed clinically and microscopically in rabbits [30].

Clinical experience in retinal toxicity studies revealed that the current recommended dose for intracameral injection of ciprofloxacin is less than $25 \mu \mathrm{g}$. In humans, intravitreal injections of ciprofloxacin $100 \mu \mathrm{g}$, ofloxacin $50 \mu \mathrm{g} / \mathrm{ml}$, trovafloxacin $25 \mu \mathrm{g}$ or less, moxifloxacin 160 $\mu \mathrm{g} / 0.1 \mathrm{ml}$ or less and pefloxacin $200 \mu \mathrm{g} / 0.1 \mathrm{ml}$ are considered nontoxic to the retina and intraocular structures [31].

\section{Antifungal Agents}

Fungal infections may cause severe and poor-prognosis endophthalmitis. Amphotericin B has been traditionally used for the treatment, either systemically or intravitreally usually injected at doses varying from 1 to $50 \mu \mathrm{g}$. In one study with the application of escalating doses from $10,20,30$ to $50 \mu \mathrm{g}$, the 3 higher doses of amphotericin B appeared to be associated with stronger degrees of retinal toxicity [32]. Based on animal experiments, intravitreal amphotericin $B$ in doses of 5 or $10 \mu \mathrm{g}$ remains an appropriate therapeutic option for patients with severe fungal endophthalmitis, for instance secondary to Aspergillus [32].
An alternative to amphotericin is the use of intravitreal fluconazole. An in vitro study showed no toxicity with $20 \mu \mathrm{g} / \mathrm{ml}$ exposure to fluconazole [33]. Further animal data revealed no retinal toxicity resulting from vitrectomy with a $2 \mathrm{mg} / \mathrm{ml}$ fluconazole infusion in an experimental model of candidal endophthalmitis. A single intravitreal injection of fluconazole at a concentration of $100 \mu \mathrm{g} / \mathrm{ml}$ and higher caused harmful retinal changes with disorganization of the photoreceptor outer segments [34]. Clinical experience revealed that intravitreal injection of $10 \mu \mathrm{g} / 0.1 \mathrm{ml}$ fluconazole may be the safe dosage for intraocular fungal infection [32].

New-generation triazoles, including voriconazole, posaconazole and ravuconazole, have been shown in laboratory studies and clinical experience to have very good safety profiles with few side effects [35]. Regarding toxicity, Gao et al. [36] showed that voriconazole did not cause any retinal damage by either ERG or histological studies when the intravitreal concentration was $25 \mu \mathrm{g} / \mathrm{ml}$. When the voriconazole concentration increased to $50 \mu \mathrm{g} / \mathrm{ml}$, focal areas of retinal necrosis were seen; however, electroretinograms remained unaffected. With these results, they postulated that intravitreal injections of up to 100 $\mu \mathrm{g} / \mathrm{ml}$ could be safe for the human eye. Sen et al. [37] demonstrated 5 cases of culture-proven fungal endophthalmitis. In all cases, the drug was administered at 50 $\mu \mathrm{g} / 0.1 \mathrm{ml}$, giving a final concentration of $12.50 \mu \mathrm{g} / \mathrm{ml}$ in the vitreous cavity [37]. No sign of retinal toxicity was observed: $60 \%$ had anatomical success and also $60 \%$ had a final visual acuity of counting fingers or better [37].

\section{Antiviral Agents}

Ganciclovir is commonly used in the antiviral treatment of CMV infection. Ganciclovir dosages of up to 200 $\mu \mathrm{g} / 0.1 \mathrm{ml}$ appear to be safe for serial intravitreal injections in rabbit eyes following vitrectomy and silicone oil insertion. In nonvitrectomized eyes, ganciclovir in doses $>300 \mu \mathrm{g}$ induced severe morphological retinal damage, although at a lower dose of $200 \mu \mathrm{g}$, ganciclovir caused only minor functional damage characterized by changes in the ERG b-wave in rabbits [26]. Similar to other types of antibiotics, ganciclovir also induces sporadic cases of macular infarction in patients. A case report of inadvertent intravitreal injection of a high dose of ganciclovir (40 $\mathrm{mg} / 0.1 \mathrm{ml}$ ) for CMV retinitis in a patient with AIDS led to permanent retinal damage and visual loss [38]. Recently, ganciclovir was administered as consecutive intravitreal injections in doses varying from $400 \mu \mathrm{g}$ to $5 \mathrm{mg}$ for treating intraocular viral infections [39]. 
Foscarnet is a phosphonic acid derivative (Foscavir, Astra Zeneca, London, UK) an antiviral medication used to treat herpesviruses, including CMV and herpes simplex virus types 1 and 2. Foscarnet is used intravenously, but there are some reports involving intravitreous injection for CMV retinitis. The largest cohort is a retrospective study with 193 patients submitted to intravitreal injection of $2.4 \mathrm{mg} / 0.1 \mathrm{ml}$ foscarnet. There was good clinical response regarding toxicity/complications in 301 treated eyes, where 15 had retinal detachment, 13 intravitreal hemorrhage, 3 endophthalmitis and 2 cataracts. Intravitreal foscarnet appears to be an alternative treatment for patients, where intravenous anti-CMV drugs are not tolerated or affordable, but the complications of this treatment should be considered [40]. López-Cortés et al. [41] performed an experimental study in rabbits to evaluate the pharmacokinetics of intravitreal ganciclovir (196 and $800 \mu \mathrm{g}$ ) and foscarnet $(960 \mu \mathrm{g})$. Both doses of ganciclovir yielded retinal levels above the mean inhibitory concentration against most human CMV isolates for more than $60 \mathrm{~h}$, while foscarnet retinal levels were lower than the CMV mean inhibitory concentration by $36 \mathrm{~h}$ after drug administration. These results suggest that the intravitreal administration of ganciclovir has a better pharmacokinetic profile than does foscarnet for the treatment of CMV retinitis, requiring fewer injections, which is particularly important in viral retinitis [41].

Fomivirsen sodium (Vitravene, Isis 2922; Isis Pharmaceuticals, Carlsbad, Calif., USA) is the latest addition to the armamentarium of treatment options for local CMV retinitis. Fomivirsen is a phosphorothioate oligonucleotide, which is administered intravitreally; it inhibits CMV replication through an antisense mechanism, binding to viral messenger RNA and blocking its transcription. The FDA approved fomivirsen in August 1998, as highly active antiretroviral therapy began to dramatically decrease the incidence of CMV retinitis. Clinical experience with intravenous fomivirsen is limited, where the recommended dose is $300 \mu \mathrm{g}$ every other week for 2 doses followed by maintenance doses every 4 weeks after induction. Reported adverse effects with the approved dosage include transient and reversible inflammation in the anterior chamber (19\%), increase in intraocular pressure (IOP; 19\%), vitreitis (11\%) and uveitis (5\%); cataract (9\%) has also been reported [42]. Isolated case reports describe foveal RPE stippling with reversible bull's eye maculopathy [43], peripheral RPE stippling associated with visual field loss [44] and marked retinal toxic side effects after $495-\mu \mathrm{g}$ doses [45]. Bull's eye maculopathy was diagnosed after five $330 \mu \mathrm{g}$ doses in 1 case and after 15 injections bilaterally in another. In both cases, fomivirsen was administered every other week; RPE stippling was diagnosed after weekly injections of $165 \mu \mathrm{g}$ for 3 weeks.

Cidofovir or hydroxyphosphonylmethoxypropyl cytosine has been shown to be a potent inhibitor of CMV proliferation in vitro. A single intravitreal injection of cidofovir was able to prevent progression of herpes simplex virus type 1 retinitis for an almost 10 times longer period of time than with a single intravitreal injection of ganciclovir in a rabbit model [46-50]. No signs of retinal toxicity were found at the doses $\leq 100 \mu \mathrm{g} /$ eye injected intravitreally in rabbits and Papio cynocephalus monkeys [48]. Phase I/II clinical studies showed that a single intravitreal injection of $20 \mu \mathrm{g}$ of cidofovir was safe and efficacious against CMV retinitis in human eyes for a median time of 55 days. At higher doses (40-100 $\mu \mathrm{g} / \mathrm{eye})$, however, the drug caused irreversible ocular hypotony in 33\% (at $40 \mu \mathrm{g}$ ) and $100 \%$ (at $100 \mu \mathrm{g}$ ) of eyes $[51,52]$.

Recently, an experimental study investigated the highest nontoxic dose of hexadecyloxypropyl cyclic hydroxyphosphonylmethoxypropyl adenine (HDP-cHPMPA), a novel, potent, intravitreally injectable, slow-release crystalline drug for long-acting treatment of CMV retinitis. Three doses (55, 100 and $550 \mu \mathrm{g} /$ eye) were tested in 9 pigmented rabbits, and a confirmation toxicity study with the dose equivalent to the highest nontoxic dose in rabbits was performed in 9 guinea pig eyes (a second species) to study the potential adverse effect on IOP. Intravitreal injection of the highest nontoxic dose of $55 \mu \mathrm{g} /$ eye of HDP-cHPMPA in rabbit eyes yields a calculated intravitreal concentration of $65 \mu \mathrm{M}$, which is 3,250-fold greater than the $50 \%$ effective concentration against human CMV $(0.02 \mu \mathrm{M})$. Regarding IOP, the drug did not cause hypotony in rabbit and guinea pig eyes. Finally, HDPcHPMPA could be detected in the vitreous cavity over 4 months after the injection [53].

\section{Antimetabolites and Antineoplastic Drugs}

5-Fluorouracil

5-FU is a potent antimetabolite that inhibits the proliferation and contraction of intraocular fibroblasts and the RPE in animal models and in vitro studies. 5-FU is converted inside the cell to fluoropyrimidine nucleotides that act blocking DNA synthesis due to the inhibition of thymidylate synthetase and decrease RNA function secondary to incorporation of 5-FU metabolites into newly synthesized RNA. The antiproliferative and anticontractile effects of 5-FU are probably due to the synthesis of abnormal RNA [54, 55]. 
Several studies have evaluated the retinotoxicity of 5 -FU in animal models $[54,56,57]$. Blumenkranz et al. [54] found that 5-FU was not toxic to rabbit retina after a single intravitreal dose of $2.5 \mathrm{mg}$ in nonvitrectomized eyes or after subconjunctival injections of $10 \mathrm{mg}$ daily for 7 days. Also, Barrada et al. [58] found $750 \mu \mathrm{g}$ of intravitreal 5-FU to be nontoxic in primate eyes. However, when combined with 0.10 or $0.15 \mu \mathrm{g} / \mathrm{ml}$ of vincristine, toxic effects were observed. Leon et al. [59] studied the retinotoxicity of 5-FU, assessing protein synthesis in the rabbit retina, and their data showed marked inhibition after $2.5 \mathrm{mg}$ of 5-FU, using 3 different methods for protein synthesis evaluation in the rabbit retina. Finally, Kivilcim et al. [60] showed that in silicone-filled eyes, the safe dose is up to $200 \mu \mathrm{g}$, and therefore the vitreous status is important to know before intravitreal administration of 5-FU. In another study, Cardillo et al. [61] designed a sustained-release pellet of $1.5 \mathrm{mg}$ naproxen and 5-FU with continuous drug delivery. In this study, there were no drug-related toxic effects evident on histopathological or ERG examination of eyes containing the naproxen/5-FU pellet [61].

In humans, 5-FU was used to inhibit PVR after vitrectomy. In a randomized clinical trial, 5-FU $10 \mathrm{mg}$, given as a single intravitreal injection, was evaluated in 26 vitrectomized eyes [62]. It was reported that corneal edema was slightly more prevalent in the 5-FU group and that persistent retinal damage was not observed, based on visual acuity [54].

\section{Mitomycin C}

Mitomycin C (MMC) is an anticancer drug that covalently binds to DNA and causes DNA cross-linking and cell death. This drug is not currently being used intravitreously in humans, although several ophthalmic experimental studies have been carried out $[56,63]$.

The toxicity of $0.2,0.3$ and $0.4 \mathrm{mg} / \mathrm{ml} \mathrm{MMC}$ to the rat retina was investigated by Kawashima et al. [64], who reported that ERG changes follow intravitreal injection. No signs of retinal toxicity were observed after $0.2 \mathrm{mg} /$ $\mathrm{ml}$ at 7 days, mild changes with $0.3 \mathrm{mg} / \mathrm{ml}$ at 7 days and profound damage with $0.4 \mathrm{mg} / \mathrm{ml}$ in as early as 2 days. The highest dose $(0.4 \mathrm{mg} / \mathrm{ml})$ showed selective degeneration of Müller cell processes on day 2, RPE changes on day 4 and irregular arrangement of the outer nuclear layer and photoreceptors on day 7. MMC $(0.4 \mathrm{mg} / \mathrm{ml})$ administered in the anterior chamber showed no evidence of ERG and histological changes at 2 and 7 days after injection [64]. Macky et al. [63] evaluated the retinal toxicity of intravitreal injection of MMC combined with TA $(0.784 \mu \mathrm{g} / 0.2 \mu \mathrm{l})$ in rats. No difference was ob- served between MMC-TA conjugate and a control group, based on histopathology and electroretinogram 5 or 20 days after treatment. No signs of retinal damage such as retinal necrosis, photoreceptor cell loss, cystic degeneration or inflammatory cell infiltration were observed [63].

Mitomycin was also investigated in rabbit eyes. Velez et al. [65] showed no ERG abnormalities after intravitreal injection of $2 \mu \mathrm{g} / 0.1 \mathrm{ml}$. On the other hand, $4 \mu \mathrm{g} / 0.1 \mathrm{ml}$ caused a decrease of $34.5 \%$ in the b-wave, and with $8 \mu \mathrm{g} / 0.1 \mathrm{ml}$, the b-wave was absent. In a PVR model, $\mathrm{Yu}$ and Chung [66] evaluated the safety and efficacy of MMC in a PVR rabbit model. Regarding safety, a dosage of up to $4 \mu \mathrm{g} / 0.1 \mathrm{ml}$ was not toxic in nonvitrectomized rabbits, but in gas-filled eyes, the safe dose was $2 \mu \mathrm{g} / 0.1 \mathrm{ml}$. In the PVR rabbit model of intravitreal injection of RPE cells, there was a remarkable reduction in advanced retinal detachment after intravitreal MMC, 9.1\% with the $0.2-\mu \mathrm{g}$ dose and no occurrence with the 1.0- $\mu$ g dose, compared to $84.6 \%$ in untreated eyes [66]. There are no reports of the use of intravitreal MMC in humans; however, based on experimental studies the safe dose varies from 2 to $4 \mu \mathrm{g} / 0.1 \mathrm{ml}$.

\section{Colchicine}

Colchicine, a mitosis-arresting phenanthrene derivative extracted from various species of Colchicum (especially C. autumnale), is a drug commonly used in the prophylaxis and treatment of gout, by inhibiting cell proliferation and acting as an anti-inflammatory drug. This drug is known to be neurotoxic, and peripheral neuropathy associated with its use has been described clinically. This drug is not currently being used intravitreously in humans, although several experimental ophthalmic studies have been carried out [67].

The effects of 1.0-100 $\mu \mathrm{g}$ of intravitreal colchicine in monkeys were studied by ophthalmoscopy, and light and electron microscopy. Optic nerve atrophy was ophthalmoscopically evident within 4 weeks after a single dose of $10 \mu \mathrm{g}$ or more [68]. Morphological changes included progressive swelling of retinal neurons, accumulation of a fibrillogranular material, displacement of organelles and loss of microtubules. Cell membrane rupture was observed in ganglion cells and in photoreceptors after as little as $1 \mu \mathrm{g}$ of colchicine [68], while relative sparing of the cone cells was noted. Similar effects were observed after intravitreous injection of colchicine in the rabbit, cat and rat. However, the monkey retina appears to be more sensitive to colchicine [67]. 


\section{Methotrexate}

Methotrexate (MTX) is an antineoplastic agent used to treat a variety of malignant conditions. It reversibly bind s to and inhibits dihydrofolate reductase, which leads to a depletion of purine and thymine nucleotides, consequently blocking DNA, RNA and protein synthesis. MTX affects cells in the $S$ phase of the cell cycle [69], and it is most effective against rapidly proliferating cells. MTX is mostly used in combination with other antineoplastic agents in the treatment of the ocular neoplasias $[65,69$, 70].

Velez et al. [65] evaluated the ocular toxicity of intravitreal combination chemotherapy, composed of 3 cycles of serial injections of MTX (400 $\mu \mathrm{g}$ on days 1, 4 and 6), a single injection of 5-FU (500 $\mu$ g on day 2$)$ and dexamethasone (500 $\mu$ g on day 7). The investigation was performed in New Zealand white rabbits, and fluctuations in the aand b-wave amplitudes in both the experimental (right) and control (left) eyes were observed. Full recovery was noted, however, with no statistically significant difference in the mean of the a- and b-wave amplitudes between the treated and control eyes after the final cycle [65]. Histopathological examination confirmed ERG findings, showing no photoreceptor or ganglion cell layer damage in the experimental eyes compared with controls, away from the site of injection. The optic nerve and medullary rays also appeared intact in both the treated and control eyes [65]. Another study determined the retinal toxicity of combined chemotherapy in rabbit eyes, which consisted of: 5-FU, $375 \mu \mathrm{g}$; doxorubicin, $3 \mu \mathrm{g}$; neomycin, $15 \mu \mathrm{g}$; thiotepa, $12 \mu \mathrm{g}$; etoposide, $150 \mu \mathrm{g}$, and MTX, $600 \mu \mathrm{g}$. This combination regimen caused a severe ERG decrease (decrease in b-wave amplitude to less than $25 \%$ ) and retinal changes (generalized thinning of the retina, disorganization of retinal layers and loss of photoreceptor outer segments) [71].

In humans, MTX has been used in both inflammatory and neoplastic ophthalmic disease. Intravitreal MTX has been effectively used in the treatment of intraocular lymphomas, both in primary central nervous system lymphoma and non-Hodgkin's lymphoma [72]. It has also been used in eyes with uveitis and advanced proliferative diabetic retinopathy $[70,73]$. Adverse reactions to intraocular MTX have been reported, where corneal epitheliopathy is the main complication, followed by corticosteroid-responsive sterile endophthalmitis and less common intravitreal hemorrhage. Cataract was probably related to MTX toxicity, but no special type of cataract was noted. Other conditions, including irreversible loss of visual acuity, maculopathy and progression of cataract, could not be directly attributed to the injection since these complications occurred in patients with previous severe disease $[70,73]$. A single intravitreal MTX injection $(200$ or $400 \mu \mathrm{g})$, used in the treatment of proliferative diabetic retinopathy and chronic uveitis, was also studied, and the authors did not report any adverse effect [74]. The cumulative intravitreal MTX dose ranging from 200 to $1,200 \mu \mathrm{g}$ in silicone-filled eyes was studied, and no adverse effects were observed following single or serial injections at doses up to $1,200 \mu \mathrm{g}$ [75].

\section{Melphalan}

Melphalan, also known as L-phenylalanine mustard, phenylalanine mustard or L-sarcolysin, is a phenylalanine derivative of nitrogen mustard. Melphalan is a bifunctional alkylating agent, which is active against selective human neoplastic diseases [76]. It is FDA approved for palliative therapy of multiple myeloma and nonresectable epithelial carcinoma of the ovary. Considering ocular tumors, melphalan has been used in cases of advanced retinoblastoma, injected intravitreously and into the ophthalmic artery [77].

Ueda et al. [76] studied the effects of an intravitreal injection of melphalan on electroretinography and on the retinal structure in rabbits to establish the nontoxic dose for its clinical use. They concluded that $5.9 \mu \mathrm{g} / \mathrm{ml} \mathrm{mel-}$ phalan was not toxic; this concentration was higher than the $4 \mu \mathrm{g} / \mathrm{ml}$ necessary to completely suppress colony formation by retinoblastoma cells in vitro [76]. Another study investigated the toxic effects of intravitreal perfusion with melphalan $(5,10$ and $20 \mu \mathrm{g} / \mathrm{ml})$ during vitrectomy on the rabbit retina. In the $5 \mu \mathrm{g} / \mathrm{ml}$ perfusion group, electroretinograms and histology showed no substantial changes compared with control fellow eyes during 28 days postoperatively. However, the groups of 10 and 20 $\mu \mathrm{g} / \mathrm{ml}$ displayed a decreased a- and b-wave amplitude and histological changes [78].

In humans, Kaneko and Suzuki [79] reported the treatment of 41 eyes with intravitreous injection of melphalan for retinoblastoma; 56.1\% (23/41) of these eyes were salvaged, and $43.9 \%$ (18/41) of these eyes were enucleated in the long run. Severe side effects, such as extraocular dissemination of tumor cells related to intravitreal injection, were not experienced [79]. Vitreous injection of melphalan may be one of the promising treatment modalities for conservative therapy.

Investigators in Japan developed a technique to deliver chemotherapy to the orbit by temporarily occluding the carotid artery distal to the ophthalmic artery and injecting intra-arterial melphalan into the cervical internal ca- 
Table 2. Current and future $m A b s$ in the treatment of ocular diseases

\begin{tabular}{|c|c|c|c|c|c|c|c|c|}
\hline Drug name & $\begin{array}{l}\text { Brand } \\
\text { name }\end{array}$ & Company & Target & $\begin{array}{l}\text { Antibody } \\
\text { composition }\end{array}$ & Current indications & Future indications & $\begin{array}{l}\text { Level of evidence } \\
\text { in ophthalmology }\end{array}$ & $\begin{array}{l}\text { FDA status in } \\
\text { ophthalmology }\end{array}$ \\
\hline Adalimumab & Humira & Abbott & TNF- $\alpha$ & Fully human & $\begin{array}{l}\text { Uveitis and inflammatory } \\
\text { diseases }\end{array}$ & $\begin{array}{l}\text { Wet AMD and macular } \\
\text { edema }\end{array}$ & $\begin{array}{l}\text { Ongoing clinical } \\
\text { trial }\end{array}$ & Off label \\
\hline Bevacizumab & Avastin & Genentech & VEGF-A & Humanized & $\begin{array}{l}\text { Wet AMD, macular } \\
\text { edema and PDR }\end{array}$ & Neovascular glaucoma & $\begin{array}{l}\text { Ongoing clinical } \\
\text { trial }\end{array}$ & Off label \\
\hline Daclizumab & Zenapax & Roche & $\mathrm{CD} 25$ & Chimeric & Uveitis & Dry AMD & Phase II & Off label \\
\hline Etanercept & Enbrel & Amgen & $\begin{array}{l}\text { TNF- } \alpha \\
\text { and }-\beta\end{array}$ & $\begin{array}{l}\text { Recombinant } \\
\text { dimeric protein }\end{array}$ & $\begin{array}{l}\text { Uveitis and inflammatory } \\
\text { diseases }\end{array}$ & $\begin{array}{l}\text { Wet AMD and macular } \\
\text { edema }\end{array}$ & $\begin{array}{l}\text { Ongoing clinical } \\
\text { trial }\end{array}$ & Off label \\
\hline Infliximab & Remicade & Centocor & TNF- $\alpha$ & Chimeric & $\begin{array}{l}\text { Uveitis and inflammatory } \\
\text { diseases }\end{array}$ & $\begin{array}{l}\text { Wet AMD and macular } \\
\text { edema }\end{array}$ & $\begin{array}{l}\text { Ongoing clinical } \\
\text { trial }\end{array}$ & Off label \\
\hline Ranibizumab & Lucentis & Genentech & VEGF-A & $\begin{array}{l}\text { Antibody } \\
\text { fragment }\end{array}$ & $\begin{array}{l}\text { Wet AMD and macular } \\
\text { edema }\end{array}$ & $\begin{array}{l}\text { Neovascular glaucoma } \\
\text { and PDR }\end{array}$ & FDA-approved & Approved \\
\hline Rituximab & Rituxican & Genentech & $\mathrm{CD} 20$ & Chimeric & $\begin{array}{l}\text { Lymphoma and } \\
\text { inflammatory diseases }\end{array}$ & Dry AMD & Phase I & Off label \\
\hline
\end{tabular}

$\mathrm{AMD}=$ Age-related macular disease; $\mathrm{PDR}=$ proliferative diabetic retinopathy; TNF = tumor necrosis factor; VEGF = vascular endothelial growth factor.

rotid [77]. Recently, a phase I/II study using this technique was published [77], where neither severe systemic side effects nor toxicity to the cornea, anterior segment, pupil or motility were reported [80]. Considering the retina, retinal ischemia was observed in 1 (previously irradiated) eye, and another eye showed no toxicity after intraarterial chemotherapy but did develop a radiation-like retinopathy after brachytherapy [80].

\section{Monoclonal Antibodies}

Current and future indications of mAbs will be discussed, and table 2 provides information on the mechanism of action, level of evidence and FDA status.

Anti-Vascular-Endothelial-Growth-Factor mAbs and Fragments: Bevacizumab and Ranibizumab

The 2 anti-VEGF (vascular endothelial growth factor) $m A b s$ bevacizumab and ranibizumab were shown to promote clinical control of ocular neovascularization in the last few years. Although endovenous administration of anti-VEGF mAbs has demonstrated an acceptable toxicity profile, their intraocular injection has decreased the risk of systemic complications. In addition, intravitreal injection of anti-VEGF agents may increase the amount of drug available to intraocular tissues such as the retina.

In vitro cellular assays of exposure to various concentrations of bevacizumab $(0.08 \mu \mathrm{g} / \mathrm{ml}$ to $1 \mathrm{mg} / \mathrm{ml})$ have shown few toxic effects to neuronal cells such as the gan- glion cells, neuroretinal cells and RPE cells, as well [8183]. In rabbits, $\mathrm{mAbs}$ penetrated the full thickness of the retinal tissue by $24 \mathrm{~h}$, and their presence gradually decreased to undetectable levels at 4 weeks [84]. Experiments in monkeys revealed some bevacizumab immunoreactivity in the inner layers of the retina and also in the choroid as early as 1 day after injection. Thereafter, the immunoreactivity was even more evident in the outer layers and the choroid within the following 7 days [85].

Retinal cells interact actively with cytokines and growth factors to maintain their healthy environment and to promote vision. In this context, vascular endothelial cells produce and depend on VEGF for their multiple bioactivities, thereby being susceptible to anti-VEGF drugs. To study the effects of bevacizumab on various types of retinal cells, Kaempf et al. [86] exposed cultured adult porcine neurosensory retinas joined to the RPE/ choroid layer to 3 doses of bevacizumab $(0.25,0.5$ and $1.25 \mathrm{mg} / \mathrm{ml}$ ) for 3 days. Their results showed no toxic effects on ganglion or photoreceptor cells at any concentration of bevacizumab. However, they observed significantly enhanced smooth muscle actin expression in retinal blood vessels in the presence of bevacizumab, which may imply a loss of smooth muscle cell modulation in normal retinal vessels by VEGF [86]. In contrast to those data, Luthra et al. [83] found no toxicity to microvascular retinal cells in vitro after their exposure to $0.125,0.25$, 0.50 and $1 \mathrm{mg} / \mathrm{ml}$ bevacizumab for up to $24 \mathrm{~h}$. 
Fig. 3. A Figure shows electroretinography study performed in non-human primates after intravitreal injection of infliximab. B $40 \times$ light microscopy (LM) with toluidine blue staining with normal non-human primate's retina after $400 \mu \mathrm{g}$ intravitreal injection. C Normal retinal pigmented epithelium of the same area shown in LM slide in transmission electron microscopy $(10,000 \times)$.
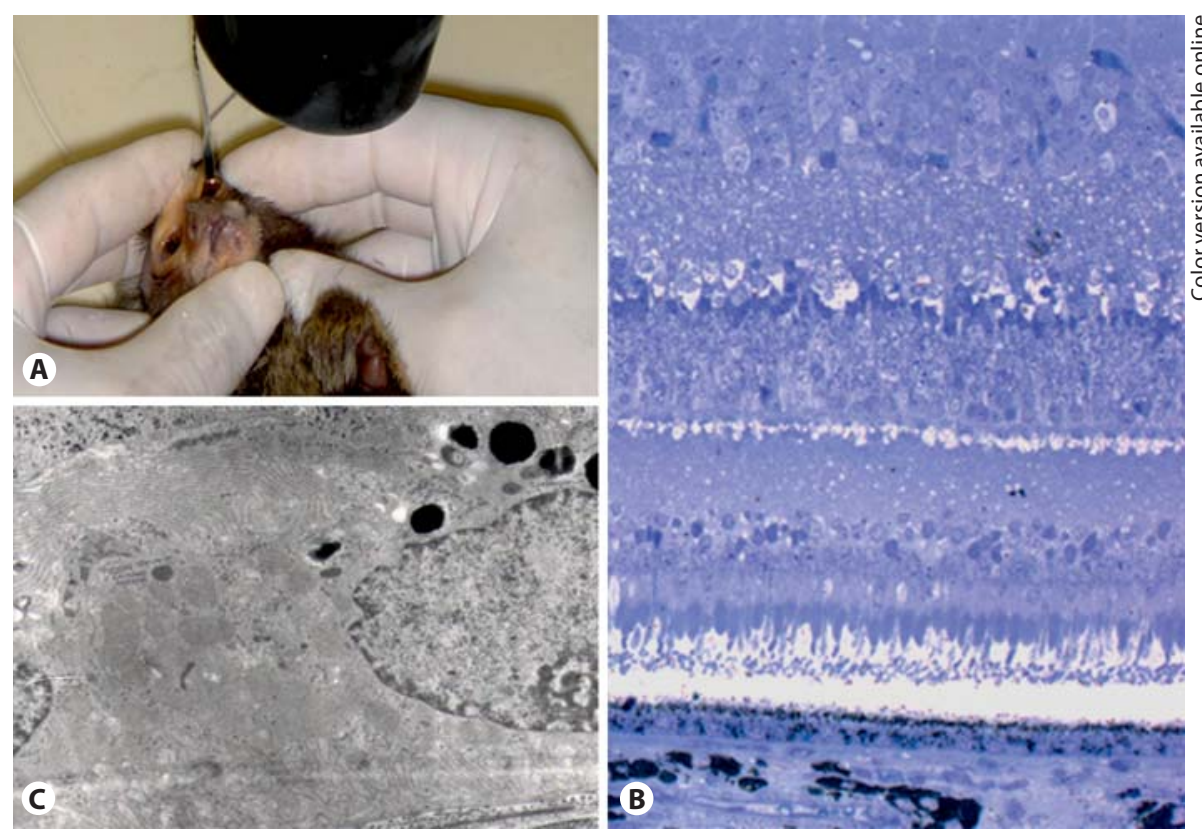

A large body of animal studies has been released about the biocompatibility and safety of bevacizumab for ophthalmology. Consecutive experimental investigations in rats, rabbits and primates revealed that intravitreal bevacizumab at various concentrations up to $3 \mathrm{mg} / \mathrm{ml} \mathrm{dem}$ onstrated no functional or morphological toxicity to the retina [84, 87-89]. The preclinical safety of ranibizumab has been evaluated in primate eyes, showing that $0.5 \mathrm{mg}$ injection of the $\mathrm{mAb}$ fragment caused reduced leakage from choroidal neovascularization, while no signs of retinal toxicity have been encountered [90].

However, a few recent reports of experimental studies demonstrated some signs of retinal damage after intravitreal bevacizumab. In primates, intravitreal bevacizumab induced choriocapillaris abnormalities manifested by reduced choriocapillaris endothelial cell fenestrations by densely packed thrombocytes and leukocytes within the vascular lumen [91]. Moreover, Manzano et al. [88] reported signs of ocular inflammation after intravitreal injection of high-dose bevacizumab at $5 \mathrm{mg}$ in rabbit eyes. Also in rabbits, intravitreal bevacizumab at a dose of 1.25 or $3 \mathrm{mg}$ caused both mitochondrial changes in the inner segments of photoreceptors and intensive apoptotic protein expression of bax and caspase on immunohistochemistry in comparison to control [87], but no signs of toxicity were detected on light microscopy and ERG examination. The clinical importance of such findings is yet to be clarified.

Retinal and Ocular Toxicity in Ocular Application of Drugs and Chemicals II
Regarding human studies, to date intraocular bevacizumab and ranibizumab injections have produced few clinically important ocular side effects. In contrast to the crystalline steroid drug TA, intravitreal bevacizumab has not been shown to induce glaucoma or cataract progression. Further clinical experience with intravitreal bevacizumab revealed few sporadic cases of uveitis, vitreous hemorrhage, RPE tears or endophthalmitis [92, 93].

Clinically, Rosenfeld et al. [94] suggested that the maximum tolerated dose of ranibizumab is $0.5 \mathrm{mg}$, as higher doses over $1 \mathrm{mg}$ caused clinically important intraocular inflammation. Additional clinical investigation disclosed that intravitreal ranibizumab induces few severe complications such as endophthalmitis, uveitis and vitreitis in the fellow eye, while minor ocular events reported were conjunctival bleeding, eye pain and floaters $[92,95,96]$. In 2008, a head-to-head comparison of ranibizumab versus bevacizumab to treat advanced age-related macular degeneration funded by the National Eye Institute was started, which should clarify the differences in safety issues between the two mAbs (http://www.nei.nih.gov/ news/statements/amd_therapy.asp).

Anti-Tumor-Necrosis-Factor mAbs: Etanercept,

Infliximab and Adalimumab

Three anti-TNF (tumor necrosis factor) agents, infliximab, etanercept and adalimumab, have been shown to 
promote clinical control of uveitis and other inflammatory eye diseases $[97,98]$.

Although infliximab and etanercept have been mainly administered systemically, in the future, anti-TNF mAbs may be used in intraocular therapy for the management of severe intraocular inflammatory and angiogenic diseases. Intravitreal injections of infliximab at concentrations $\leq 1.7 \mathrm{mg}$ have been shown to be safe to the retinal tissue in preliminary animal studies, although future detailed research should elucidate the intraocular safety and pharmacokinetics of infliximab and its vehicle [99]. Recently, our group investigated the intravitreal toxicity of infliximab in nonhuman primates, and it was shown to be safe up to a dose of $400 \mu \mathrm{g}$ (fig. 3) [unpubl. data]. The pharmacokinetics and safety of intravitreal etanercept delivery at a dose of $100 \mu \mathrm{g}$ have been investigated in rabbits in one study. Clinical examination, electroretinography and histology revealed no evidence of toxicity with retinal levels peaking at 4 weeks and still detectable after 8 weeks [100]. Another investigation on the intraocular safety of different doses of etanercept revealed that the anti-TNF $\mathrm{mAb}$ at doses up to $2.5 \mathrm{mg}$ caused no retinal damage [101]. One study recently demonstrated the safety profile of intravitreal injections of various doses of adalimumab in rabbits. Their results showed normal retinal examination in eyes having received injections of balanced salt solution (BSS), 0.25 or $0.50 \mathrm{mg}$ adalimumab; however, $1 \mathrm{mg}$ adalimumab induced inflammatory changes, retinal histopathological alterations and significant ERG reduction [102]. In summary, most studies suggest a dose-dependent retinal toxicity profile for intravitreal anti-TNF $\mathrm{mAbs}$, and further evaluation should determine the exact safe dosage for each drug.

Interestingly, large clinical trials have poorly addressed ocular complications after the systemic application of anti-TNF mAbs. Neuro-ophthalmic toxic effects of systemic infliximab, adalimumab and etanercept have been manifested by either anterior optic nerve neuropathy or oculomotor nerve palsy, and over 15 cases of optic neuritis have been reported $[103,104]$. Ocular side effects such as cataracts, infections or increase in IOP have not been observed, although one study suggested the occurrence of mild vitreous hemorrhage in 2 patients [104, 105].

Anti-Cluster-of-Differentiation Antigen mAb:

Rituximab

A few additional mAbs, including rituximab, daclizumab, efalizumab and alemtuzumab, showed positive results in animal and early clinical studies, and may rep- resent useful adjuvant therapies for ocular lymphoma or ocular inflammation.

Rituximab (Rituxan ${ }^{\circledR}$, Genentech, San Francisco, Calif., USA) is the chimeric $\mathrm{mAb}$ against cluster of differentiation 20 (CD20) antigen that was FDA approved as subcutaneous infusion for patients with recurrent low-grade B-cell lymphoma, while it may also be indicated for rheumatoid arthritis systemic lupus erythematosus, leukemia and Wegener's granulomatosis [106]. Small clinical series revealed rituximab as an effective treatment for patients with refractory scleritis, orbital inflammation, and intraocular and extraocular lymphoma [103]. The intravitreal pharmacokinetics of rituximab has recently been investigated; high concentrations of anti-CD20 mAb were sustained, with a half-life of 4.7 days in one study, whereas in a second investigation the agent injected intravitreally at doses up to $1 \mathrm{mg}$ induced neither retinal damage in rabbits nor clinical signs of toxicity in a small series of 5 patients [107, 108]. Comprehension of the intraocular safety of rituximab may enable intravitreal injection for the therapy of uveal/oculocerebral lymphoma and uveitis. Clinically, the anti-CD20 mAbs showed benefit in the therapy of intraocular lymphoma and uveitis, although much more clinical experience is warranted to clarify the indications and risks of anti-CD $\mathrm{mAb}$.

\section{Nonsteroidal Anti-Inflammatory Drugs}

Nonsteroidal anti-inflammatory drugs have cystoid macular edema as their main indication for retina pharmacotherapy. They may be used either systemically or topically, and topical ketorolac, diclofenac and nepafenac are most frequently used. The use of both diclofenac and ketorolac as intravitreal injections has been assessed in rabbits. Diclofenac formulated in hyaluronan was toxic to the retina at doses $\geq 540 \mu \mathrm{g}$, as evidenced by indirect ophthalmoscopy, and light and electron microscopy. Electroretinography showed no toxic signs of intravitreal injection of $400 \mu \mathrm{g}$ for this formulation after 25 days. Another study showed no signs of toxicity, either electroretinographically or histologically, of intravitreal injections of up to $300 \mu \mathrm{g}$ of diclofenac and 3,000 $\mu \mathrm{g}$ of ketorolac, after 8 weeks [109]. Preservative-free ophthalmic solution of 0.25 or $0.5 \%(500 \mu \mathrm{g})$ ketorolac tromethamine in $0.1 \mathrm{ml}$ was nontoxic to the retina in animals when assessed up to 4 weeks after injection, as shown by microscopic and ERG evaluation [109]. However, commercially available ketorolac $(3 \mathrm{mg} / 0.1 \mathrm{ml})$ was toxic following multiple intravitreal injection in albino rabbit eyes [110].

Flurbiprofen is a member of the phenylalkanoic acid derivative family of nonsteroidal anti-inflammatory 
drugs used to treat the inflammation and pain of arthritis. Morales et al. [111] investigated the retinal toxicity of intravitreal ketorolac Tris salt and flurbiprofen. Clinical examination, electroretinography results and histological evaluation demonstrated no signs of retinal toxicity for either drug at any dose (125, 250 or $500 \mu \mathrm{g}$ or $1 \mathrm{mg})$.

Finally, intravitreal use of nonsteroidal anti-inflammatory drugs has not been assessed in depth in humans to date. Unlike corticosteroids, the nonsteroidal anti-inflammatory drugs may not be associated with a rise in IOP.

\section{Enzymes and Fibrinolytics}

Pharmacological vitreolysis refers to the capacity of altering the molecular organization of the vitreous to achieve posterior vitreous detachment (PVD) induction and liquefaction. Thus, many pharmacological agents have been studied with the aim of inducing PVD in order to facilitate the surgical procedure and reduce complications of vitrectomy. Tissue plasminogen activator, plasmin, microplasmin and hyaluronidase have shown an ability to induce PVD, when given as a single intravitreal injection in experimental and human studies [112].

Tissue plasminogen activator safety was assessed experimentally in both rabbits and cats. It was injected intravitreally (doses from 50 to $100 \mu \mathrm{g}$ ), and mild to severe vitreous inflammation with or without vitreous strands was observed. Reduced scotopic a-waves and b-waves on electroretinography as well as diffuse pigment alterations, severe photoreceptor losses coupled with RPE necrosis and proliferation with pigment clumping have been documented [113]. The clinical experience available points out that doses of $25-50 \mu \mathrm{g}$ of intravitreal tissue plasminogen activator injection may be safe to the retina.

Microplasmin is a recombinant protein limited to the enzymatic moiety of plasmin without any of its cringle domains. Its enzymatic activity is similar to that of the enzyme plasmin. De Smet et al. [114] evaluated the vitreolytic ability in a porcine model with escalating doses of microplasmin $(62.5,125,250,400 \mu \mathrm{g})$ for $1 \mathrm{~h}$ or with $125 \mu \mathrm{g}$ microplasmin with increasing time of exposure $(15,30,60,120 \mathrm{~min})$. PVD was assessed by scanning electron microscopy, and microplasmin caused vitreolysis and posterior vitreous separation in an apparent doseand time-dependent fashion. In this model system, the minimal effective dose appeared to be $125 \mu \mathrm{g}$ and no signs of retinal toxicity were observed [114].

Intravitreal injection of recombinant microplasmin at doses from 12.5 to $250 \mu \mathrm{g}$ in the rabbit induces no ERG or retinal ultrastructural abnormalities. Thrombogenics
NV (Euronext Brussels, Leuven, Belgium), a biotechnology company focused on vascular disease, announced the results of the MIVI-I phase IIa trial (Microplasmin in Vitrectomy), which included 60 patients. Preliminary results available for all patients through 28 days after vitrectomy revealed that microplasmin was generally well tolerated even up to the highest dose tested $(125 \mu \mathrm{g})$ [112].

Hyaluronidase cleaves the glycosidic bonds of hyaluronan as well as other mucopolysaccharides resulting in dissolution of hyaluronan and collagen complex and subsequent vitreous liquefaction. Intravitreal injection of hyaluronidase in doses of $20 \mathrm{IU}$ or less does not appear to adversely affect the biomicroscopic morphology or function of ocular structures in a preclinical investigation in rabbits. A preservative-free, highly purified ovine hyaluronidase formulation (Vitrase, ISTA Pharmaceuticals, Irvine, Calif., USA) has been evaluated in phase III clinical trials. Intravitreal application of hyaluronidase was well tolerated, where dose-dependent iritis was the most common adverse event, occurring in $62 \%$ of eyes treated with $55 \mathrm{IU}$ and in 59\% of eyes treated with 75 IU. Iritis was often self-limited and did not result in a serious adverse event in any hyaluronidase-treated eye [112]. Wang et al. [115] conducted an experimental study in diabetic and healthy rats, evaluating PVD induction after intravitreal injection with hyaluronidase, plasmin, hyaluronidase plus plasmin and BSS used as control. Scanning electron microscopy showed that complete PVD was found after hyaluronidase and plasmin in healthy rats. However, in diabetic rats, hyaluronidase alone was ineffective, plasmin alone induced partial PVD, and the combination of hyaluronidase and plasmin induced complete PVD. No obvious toxic reaction was observed in any group [115].

\section{Miscellaneous Anti-Inflammatory and Antiangiogenic Agents}

Some forms of drugs are characterized by a wide variety of actions due to their complex chemical structure and receptor affinity. Two examples of such drugs are thalidomide and MTX. Thalidomide is a glutamic acid derivative with proved antiangiogenic and anti-inflammatory efficacy in animal models of retinal ischemia, retinal neovascularization, uveitis and diabetic retinopathy. On the other hand, MTX is an antimetabolite and antifolate drug used in the treatment of cancer and autoimmune diseases. Due to their large variety of effects, the agents could be applied in different ophthalmic diseases; however, MTX may be indicated mainly in the therapy of primary intraocular lymphoma. 
Few consecutive investigations have examined the safety of MTX in animals. As early as 1985, it has been shown that $600 \mu \mathrm{g}$ MTX combined with other chemotherapeutic agents such as doxorubicin, 5-FU and bleomycin enhanced the risk of retinal toxicity [71]. However, in one recent study, the ocular pharmacokinetics and retinal toxicity of intravitreal MTX sodium at $400 \mu \mathrm{g}$ were studied in New Zealand white rabbits. This research group reported that intravitreal MTX, combined with FU and dexamethasone, showed no evidence of retinal toxicity determined by electroretinography and histological examination [65]. Frenkel et al. [116] reported their 10year experience with frequent intravitreal injection of MTX at $400 \mu \mathrm{g} / 0.1 \mathrm{ml}$. The effective agent rarely induced adverse reactions, the most common being self-limited corneal epitheliopathy, while the vitreoretinal involvement of lymphoma could be controlled effectively [116]. In another retrospective case series, complications that occurred during the period of treatment with intravitreal MTX included cataract (73\%), corneal epitheliopathy (58\%), maculopathy (42\%), vitreous hemorrhage (8\%) and optic atrophy (4\%). However, no patient had irreversible loss of vision that could be definitely attributed to the intravitreal injections of MTX. Overall, the intravitreal use of MTX in doses up to $400 \mu \mathrm{g}$ seems to be a safe approach in clinical practice. Although no preclinical investigation has been performed to investigate the retinal biocompatibility of thalidomide for local ocular application, one case report demonstrated corneal endothelium toxicity after oral use of the powerful agent [117].

\section{Toxicity Unrelated to the Drug}

\section{Toxicity due to Preservatives}

One of the main potential sources of bias in the assessment of retinal toxicity of certain pharmaceutical preparations is undoubtedly the adverse effect of the vehicle and preservatives.

Recently, many authors reported favorable therapeutic results after intravitreal injection of TA for the treatment of exudative age-related macular degeneration [118-122], diabetic macular edema [123, 124], proliferative diabetic retinopathy [125], macular edema due to central [126] and branch [127] retinal vein occlusion, and many other conditions. After the popularization of the intravenous administration of TA, the presence of benzyl alcohol (BA) in the Kenalog (Kenalog 40, Bristol-Myers Squibb) formulation and its deleterious effects in the intraocular environment became notorious [128-132].
Macky et al. [131] injected $0.1 \mathrm{ml}$ of pure BA in the vitreous cavity of rabbits to assess its sole toxic properties. Evaluation included IOP measurements, slitlamp examination, indirect ophthalmoscopy, electroretinogram and electron microscopy for quantitative morphometric measurements. The mean amplitudes of the $a-a n d b$-waves of the BA-injected eyes were significantly reduced compared with the BSS-injected eyes and the noninjected contralateral eyes. These ERG responses continued to be significantly reduced in the BA-injected eyes $(\mathrm{p}<0.01$, $\mathrm{t}$ test) throughout the study period. The mean ganglion cell count was significantly reduced in the BA-injected eyes compared with the BSS-injected and noninjected eyes. Electron microscopy showed moderate to severe intracellular changes in the ganglion cell layer, inner nuclear cell layer, outer nuclear cell layer and photoreceptor layer at 6 weeks in BA-injected eyes, with no significant changes in the BSS-injected eye. There was no significant rise in the IOP or clinical evidence of increased lens density during the study period in any of the eyes.

Lang et al. [133] compared intravitreal injection of commercial Kenalog versus its vehicle alone, pure triamcinolone or BSS. Kenalog and its vehicle alone caused approximately $50 \%$ reduction in the ERG b-wave amplitude at the end of follow-up. Pure TA caused only mild (up to 14\%) reduction of the ERG b-wave amplitude. Histological examination of the retina exposed to Kenalog or its vehicle showed severe damage to all retinal layers in areas close to the site of Kenalog injection. The authors of this study emphasized that a simple separation of the vehicle from the TA is not absolutely safe, and even a small amount of the vehicle may still be toxic. It has also been shown that following filtered or nonfiltered separation of triamcinolone from the vehicle, the concentration of BA increased to $3.6-4.3 \%$ (compared to $0.99 \%$ in commercial Kenalog suspension distributed in the USA) due to the high affinity of BA for a lipophilic environment such as TA crystals [132].

Li et al. [134] evaluated the toxic effects of two TA vehicles separated by centrifugation from commercially available preparations - Transton (vehicle A; Kunming Jida, China) and Kanacort-A (vehicle B; Bristol-Myers Squibb, Pakistan) - on rabbit retina at two different volumes ( 0.1 and $0.2 \mathrm{ml})$. Both vehicles $A$ and $B$ consisted of $9.9 \mathrm{mg} / \mathrm{ml} \mathrm{BA}, 7.5 \mathrm{mg} / \mathrm{ml}$ sodium carboxymethylcellulose and $0.4 \mathrm{mg} / \mathrm{ml}$ polysorbate 80 . Eyes with vehicle A appeared normal under the ophthalmoscope but showed disorganization in the retinal inner nuclear layer and photoreceptor layer in pathological analyses. Eyes with vehicle $\mathrm{B}$ disclosed more significant retinal changes in- 
cluding retinal hemorrhage, vascular narrowing, myelinated fiber edema, retinal necrosis and atrophy, and photoreceptor apoptosis. There was an increase in the degree of the above damages as the volume of either vehicle was increased.

Kai et al. [128] compared intravenous injections in rabbits of 4 or $25 \mathrm{mg}$ of TA, with vehicle either reduced or not. Elevation of IOP was noted in all experimental groups after intravitreal TA. A significant uniformly distributed increase in lens density measured by a Pentacam system was noticed 1 week after intravitreal TA in the group administered $25 \mathrm{mg}$ + vehicle. A significant loss of glutathione peroxidase activity was noticed at the end of the study, while superoxide dismutase activity increased. Since the function of glutathione peroxidase, which catalyzes the reduction of hydrogen peroxide to water, is to protect the lens from oxidative damage, the decrease in glutathione peroxidase activity may suggest damage of the antioxidative system of the lens. Amplitudes of ERG waves declined significantly in vehicle-treated groups at the end of the study. Pathological examination showed obvious retinal toxicity in vehicle-treated groups [128].

Formerly, Loewenstein et al. [135] had already reported the deleterious effects of preservatives in another frequently used commercial corticosteroid preparation, methylprednisolone acetate (Depo-Medrol ${ }^{\circledR}$; Upjohn Company, Kalamazoo, Mich., USA). At that time, myristyl- $\gamma$-picolinium chloride was found to be the major toxic component of the formulation. When myristyl- $\gamma$-picolinium chloride solutions were injected at concentrations at least twice as high as that in Depo-Medrol, significant reductions in the light- and dark-adapted ERG responses were seen. The effect of the drug on the ERG responses was seen as early as 3 days after injection and developed to its maximal level within 1-2 weeks. No ERG recovery was seen over a period of more than 2 months. The visual evoked potential, elicited by applying light stimuli to the experimental eye, was characterized by low amplitude and delayed implicit time compared with the response obtained from the control eye [135].

Recently, Lüke et al. [136] studied retinal tolerance to bevacizumab in co-application with a recombinant tissue plasminogen activator (rtPA). During application of bevacizumab $(0.25 \mathrm{mg} / \mathrm{ml})$ in co-application with $20 \mathrm{mg} / \mathrm{ml}$ rtPA, the ERG amplitudes remained stable. The concentrations of rtPA alone $(20$ and $60 \mathrm{mg} / \mathrm{ml}$ ) did not induce significant reduction of the b-wave amplitude. In addition, $20 \mathrm{mg} / \mathrm{ml} \mathrm{rtPA}$ did not alter the a-wave amplitude. However, $60 \mathrm{mg} / \mathrm{ml} \mathrm{rtPA}$ caused a slight but significant reduction in the a-wave amplitude. A full recovery was detected for both concentrations during the washout. At the highest tested concentration of $200 \mathrm{mg} / \mathrm{ml} \mathrm{rtPA}$, a significant reduction in the a- and b-wave amplitudes occurred during the exposure. The reduction of ERG amplitudes remained irreversible during the washout. The retinal toxicity of rtPA was thought to be due to the Larginine component of the vehicle [136]. Further evidence for this hypothesis comes from a study of intravitreal injections of aztreonam that also contain L-arginine in the vehicle, which showed almost equivalent retinal damage when vehicle equivalent to the aztreonam dose was injected $[137,138]$.

Many other commercially available systemic medications could probably be useful for intraocular use, but every component of the vehicle or preservative can carry in itself significant toxic potential, and much more research is still needed in this area.

\section{Toxicity due to Osmolarity and $p H$ Changes in the} Retina

The group around Marmor [139-143] first reported retinal toxicity secondary to changes in osmolarity at the vitreomacular interface. They described cellular damage at the vitreoretinal interface, including nonspecific shrinkage and disruption of the cellular architecture caused by induction of osmotic levels higher than 500 mOsm. Despite the fact that differences in osmolarities between the subretinal space and choroid are corrected rapidly by the adjacent tissues, substances with nonphysiological osmolarity can produce retinal damage when in contact with the subretinal space, as in macular hole surgery [139-143]. Intravitreal dye injections may rapidly change the osmolarity in the vitreous cavity. Several in vivo and in vitro studies proposed that hypo-osmotic indocyanine green solutions could harm the RPE, and this effect could be augmented by additional intraoperative light exposure [144-146].

It is clear that homeostatic conditions are essential for the delicate intraocular environment, and many of the recently intraocularly administered off-label drugs lack an adequate adjustment to deal with intraocular $\mathrm{pH}$ and osmolarity requirements. Moreover, the lack of definite safe ranges for these parameters in the literature makes it even more difficult to predict whether a particular pharmacological preparation is toxic or not.

Anyway, it is obvious that extreme $\mathrm{pH}$ and osmolarity values for intraocular solutions, even when only a short exposure time is intended, should be definitely avoided. 


\section{Final Conclusions}

Intravitreal pharmacotherapies have been used with increasing frequency in the treatment of retinal disease. Indications for their use include choroidal neovascular membranes, diabetic macular edema, ischemic neovascularization, inflammatory and infectious processes, and neoplasia. Complications of intravitreal therapies include cataract formation, glaucoma and endophthalmitis. Recent developments of pharmacological agents administered intravitreally and the new applications of systemic medications in retinal disease present the practitioner with expanded treatment options. Current and emerging data will help guide therapy in order to maximize the benefits and limit the systemic and ocular complications of these new treatment options.

Ocular toxicity caused by the exposure of the retinal tissue to a high concentration of drug for certain periods of time remains an important topic in the approach to intravitreal injection in the therapy of retinal diseases. In the evaluation of drug safety for retinal pharmacotherapy, both exposure concentration and exposure time can be important, but the toxic effect may also be directly related to the transient drug distribution inside the vitreous body. The retina is subject to the risk of drug-induced toxicities owing to its rich blood supply, complex neuro- retinal organization and lifelong exposure to focused light rays. To deal with the risk of injury, the retina is protected by specific defense mechanisms including the endogenous cytochrome P450 detoxification system and the blood-retina barrier. An understanding of these cellular and molecular principles is a key aspect in elucidating the pathological pathways leading to retinotoxicity.

Currently, there are several approved drugs for intravitreal use, such as ranibizumab (Lucentis; Genentech) and pegaptanib (Macugen; Pfizer, New York, N.Y., USA). However, there are numerous off-label uses of drugs and substances injected into the eye, and the scientific literature remains confusing with regard to the intraocular properties and toxicology of off-label drugs such as commercial triamcinolone, antibiotics, antivirals and tissue plasminogen activator.

In the near future, several drugs that have already undergone preclinical evaluation and small case series in patients, and that are now tested in randomized clinical trials, will be available soon for use in clinical practice.

\section{Acknowledgment}

Our thanks go to the Fundação de Amparo à Pesquisa do Estado de São Paulo.

\section{References}

$>1$ Bourges JL, Gautier SE, Delie F, Bejjani RA, Jeanny JC, Gurny R, Ben Ezra D, Behar-Cohen FF: Ocular drug delivery targeting the retina and retinal pigment epithelium using polylactide nanoparticles. Invest Ophthalmol Vis Sci 2003;44:3562-3569.

$\checkmark 2$ Clark AF, Yorio T: Ophthalmic drug discovery. Nat Rev Drug Discov 2003;2:448-459.

$\checkmark 3$ Ziche M, Donnini S, Morbidelli L: Development of new drugs in angiogenesis. Curr Drug Targets 2004;5:485-493.

4 Bhatnagar P, Spaide RF, Takahashi BS, Peragallo JH, Freund KB, Klancnik JM Jr, Cooney MJ, Slakter JS, Sorenson JA, Yannuzzi LA: Ranibizumab for treatment of choroidal neovascularization secondary to age-related macular degeneration. Retina 2007;27:846850.

5 Blick SK, Keating GM, Wagstaff AJ: Ranibizumab. Drugs 2007;67:1199-1206, discussion 1207-1199.

-6 Novack GD: Pharmacotherapy for the treatment of choroidal neovascularization due to age-related macular degeneration. Annu Rev Pharmacol Toxicol 2008;48:61-78.
7 Vavvas D, D’Amico DJ: Pegaptanib (Macugen): treating neovascular age-related macular degeneration and current role in clinical practice. Ophthalmol Clin North Am 2006; 19:353-360.

8 Ohm J: Über die Behandlung der Netzhautablösung durch operative Entleerung der subretinalen Flüssigkeit und Einspritzung von Luft in den Glaskörper. Graefes Arch Clin Exp Ophthalmol 1911;79:442-450.

$\checkmark 9$ Friedman AH, Orellana J, Freeman WR, Luntz MH, Starr MB, Tapper ML, Spigland I, Roterdam H, Mesa Tejada R, Braunhut S, Mildvan D, Mathur U: Cytomegalovirus retinitis: a manifestation of the acquired immune deficiency syndrome (AIDS). Br J Ophthalmol 1983;67:372-380.

10 Blankenship GW: Evaluation of a single intravitreal injection of 5-fluorouracil in vitrectomy cases. Graefes Arch Clin Exp Ophthalmol 1989;227:565-568.

11 Vander JF: Tissue plasminogen activator irrigation to facilitate removal of subretinal hemorrhage during vitrectomy. Ophthalmic Surg 1992;23:361-363.
12 Jaffe GJ, Yang CH, Guo H, Denny JP, Lima C, Ashton P: Safety and pharmacokinetics of an intraocular fluocinolone acetonide sustained delivery device. Invest Ophthalmol Vis Sci 2000;41:3569-3575.

13 Holekamp NM, Thomas MA, Pearson A: The safety profile of long-term, high-dose intraocular corticosteroid delivery. Am J Ophthalmol 2005;139:421-428.

14 Kwak HW, D'Amico DJ: Evaluation of the retinal toxicity and pharmacokinetics of dexamethasone after intravitreal injection. Arch Ophthalmol 1992;110:259-266.

- 15 Yu SY, Damico FM, Viola F, D’Amico DJ, Young LH: Retinal toxicity of intravitreal triamcinolone acetonide: a morphological study. Retina 2006;26:531-536.

-16 Ishibashi T, Miki K, Sorgente N, Patterson R, Ryan SJ: Effects of intravitreal administration of steroids on experimental subretinal neovascularization in the subhuman primate. Arch Ophthalmol 1985;103:708-711.

17 Maia M, Farah ME, Belfort RN, Penha FM, Lima Filho AA, Aggio FB, Belfort R Jr: Effects of intravitreal triamcinolone acetonide injection with and without preservative. Br J Ophthalmol 2007;91:1122-1124. 
-18 Dyer D, Callanan D, Bochow T, Abraham P, Lambert HM, Lee SY, Schneiderman T, Potts SL, Walker TM: Clinical evaluation of the safety and efficacy of preservative-free triamcinolone (Triesence [triamcinolone acetonide injectable suspension] $40 \mathrm{mg} / \mathrm{ml}$ ) for visualization during pars plana vitrectomy. Retina 2009;29:38-45.

-19 Moshfeghi AA, Nugent AK, Nomoto H, Sanislo SR, Kitchens JW, Moshfeghi DM: Triamcinolone acetonide preparations: impact of crystal size on in vitro behavior. Retina 2009;29:689-698.

-20 Hancock HA, Guidry C, Read RW, Ready EL, Kraft TW: Acute aminoglycoside retinal toxicity in vivo and in vitro. Invest Ophthalmol Vis Sci 2005;46:4804-4808.

-21 Oum BS, D’Amico DJ, Kwak HW, Wong KW: Intravitreal antibiotic therapy with vancomycin and aminoglycoside: examination of the retinal toxicity of repetitive injections after vitreous and lens surgery. Graefes Arch Clin Exp Ophthalmol 1992;230:56-61.

-22 D’Amico DJ, Caspers-Velu L, Libert J, Shanks E, Schrooyen M, Hanninen LA, Kenyon KR: Comparative toxicity of intravitreal aminoglycoside antibiotics. Am J Ophthalmol 1985; 100:264-275.

-23 Almeida LN, Canedo MG, Almeida RN, Almeida Sobrinho EF, Nehemy MB: Macular infarction after intravitreal injection of amikacin: case report. Arq Bras Oftalmol 2005; 68:837-840.

-24 Campochiaro PA, Green WR: Toxicity of intravitreous ceftazidime in primate retina. Arch Ophthalmol 1992;110:1625-1629.

-25 Borhani H, Peyman GA, Wafapoor H: Use of vancomycin in vitrectomy infusion solution and evaluation of retinal toxicity. Int Ophthalmol 1993;17:85-88.

-26 Hegazy HM, Kivilcim M, Peyman GA, Unal MH, Liang C, Molinari LC, Kazi AA: Evaluation of toxicity of intravitreal ceftazidime, vancomycin, and ganciclovir in a silicone oil-filled eye. Retina 1999;19:553-557.

-27 Zimmer-Galler IE, Santos A, Haller JA, Campochiaro PA: Management of endophthalmitis in a silicone oil-filled eye. Retina 1997; 17:507-509.

-28 Wiechens B, Grammer JB, Johannsen U, Pleyer U, Hedderich J, Duncker GI: Experimental intravitreal application of ciprofloxacin in rabbits. Ophthalmologica 1999;213: 120-128.

-29 Kernt M, Neubauer AS, Ulbig MW, Kampik A, Welge-Lussen U: In vitro safety of intravitreal moxifloxacin for endophthalmitis treatment. J Cataract Refract Surg 2008;34: 480-488.

-30 Aydin E, Kazi AA, Peyman GA, Esfahani MR: Intravitreal toxicity of moxifloxacin. Retina 2006;26:187-190.

-31 Thompson AM: Ocular toxicity of fluoroquinolones. Clin Exp Ophthalmol 2007;35: 566-577.
2 Khan FA, Slain D, Khakoo RA: Candida endophthalmitis: focus on current and future antifungal treatment options. Pharmacotherapy 2007;27:1711-1721.

33 Mochizuki K, Yamashita Y, Torisaki T, Komatsu K, Tanahashi T, Sakai H: Intraocular penetration and effect on the retina of fluconazole. Lens Eye Toxic Res 1992;9:537546.

34 Cheng CK, Yang CH, Hsueh PR, Liu CM, Lu HY: Vitrectomy with fluconazole infusion: retinal toxicity, pharmacokinetics, and efficacy in the treatment of experimental candidal endophthalmitis. J Ocul Pharmacol Ther 2004;20:430-438.

35 Hariprasad SM, Mieler WF, Lin TK, Sponsel WE, Graybill JR: Voriconazole in the treatment of fungal eye infections: a review of current literature. Br J Ophthalmol 2008;92: 871-878.

36 Gao H, Pennesi M, Shah K, Qiao X, Hariprasad SM, Mieler WF, Wu SM, Holz ER: Safety of intravitreal voriconazole: electroretinographic and histopathologic studies. Trans Am Ophthalmol Soc 2003;101:183-189, discussion 189.

37 Sen P, Gopal L, Sen PR: Intravitreal voriconazole for drug-resistant fungal endophthalmitis: case series. Retina 2006;26:935-939.

38 Saran BR, Maguire AM: Retinal toxicity of high dose intravitreal ganciclovir. Retina 1994;14:248-252.

39 Arevalo JF, Garcia RA, Mendoza AJ: Highdose (5,000-microg) intravitreal ganciclovir combined with highly active antiretroviral therapy for cytomegalovirus retinitis in HIV-infected patients in Venezuela. Eur J Ophthalmol 2005;15:610-618.

40 Ausayakhun S, Watananikorn S, Ngamtiphakorn S, Prasitsilp J: Intravitreal foscarnet for cytomegalovirus retinitis in patients with AIDS. J Med Assoc Thai 2005;88:103-107.

41 López-Cortés LF, Pastor-Ramos MT, RuizValderas R, Cordero E, Uceda-Montañés A, Claro-Cala CM, Lucero-Muñoz MJ: Intravitreal pharmacokinetics and retinal concentrations of ganciclovir and foscarnet after intravitreal administration in rabbits. Invest Ophthalmol Vis Sci 2001;42:1024-1028.

42 De Smet MD, Meenken CJ, van den Horn GJ: Fomivirsen - a phosphorothioate oligonucleotide for the treatment of CMV retinitis. Ocul Immunol Inflamm 1999;7:189-198.

43 Stone TW, Jaffe GJ: Reversible bull's-eye maculopathy associated with intravitreal fomivirsen therapy for cytomegalovirus retinitis. Am J Ophthalmol 2000;130:242-243.

-44 Amin HI, Ai E, McDonald HR, Johnson RN: Retinal toxic effects associated with intravitreal fomivirsen. Arch Ophthalmol 2000;118: 426-427.

45 Uwaydat SH, Li HK: Pigmentary retinopathy associated with intravitreal fomivirsen. Arch Ophthalmol 2002;120:854-857.
46 Besen G, Chavez-de la Paz E, Tatebayashi M, Flores-Aguilar M, Gangan PA, Munguia D, Wiley CA, Jahne G, Winkler I, Helsberg M, et al: Evaluation of retinal toxicity and efficacy of the anticytomegalovirus compound 2-amino-7-[(1,3-dihydroxy-2-propoxy) methyl]purine. Antimicrob Agents Chemother 1995;39:1485-1488.

-47 Besen G, Flores-Aguilar M, Assil KK, Kupperman BD, Gangan P, Pursley M, Munguia D, Vuong C, De Clercq E, Bergeron-Lynn G, et al: Long-term therapy for herpes retinitis in an animal model with high-concentrated liposome-encapsulated HPMPC. Arch Ophthalmol 1995;113:661-668.

-48 Dolnak DR, Munguia D, Wiley CA, De Clercq E, Bergeron-Lynn GL, Boscher C, Connor JD, Sherwood C, Capparelli E, Armani R, et al: Lack of retinal toxicity of the anticytomegalovirus drug (S)-1-(3-hydroxy-2-phosphonylmethoxypropyl)cytosine. Invest Ophthalmol Vis Sci 1992;33: 1557-1563.

49 Flores-Aguilar M, Huang JS, Wiley CA, De Clercq E, Vuong C, Bergeron-Lynn G, Chandler B, Munguia D, Freeman WR: Long-acting therapy of viral retinitis with (S)-1-(3-hydroxy-2-phosphonylmethoxypropyl)cytosine. J Infect Dis 1994;169:642-647.

-50 Kuppermann BD, Assil KK, Vuong C, Besen G, Wiley CA, De Clercq E, Bergeron-Lynn G, Connor JD, Pursley M, Munguia D, Freeman WR: Liposome-encapsulated (S)-1-(3-hydroxy-2-phosphonylmethoxypropyl)cytosine for long-acting therapy of viral retinitis. J Infect Dis 1996;173:18-23.

51 Kirsch LS, Arevalo JF, Chavez de la Paz E, Munguia D, de Clercq E, Freeman WR: Intravitreal cidofovir (HPMPC) treatment of cytomegalovirus retinitis in patients with acquired immune deficiency syndrome. Ophthalmology 1995;102:533-542, discussion 542-533.

52 Kirsch LS, Arevalo JF, De Clercq E, Chavez de la Paz E, Munguia D, Garcia R, Freeman WR: Phase I/II study of intravitreal cidofovir for the treatment of cytomegalovirus retinitis in patients with the acquired immunodeficiency syndrome. Am J Ophthalmol 1995; 119:466-476.

53 Tammewar AM, Cheng L, Hostetler KY, Falkenstein I, Beadle JR, Barron EC, Kozak I, Freeman WR: Intraocular properties of an alkoxyalkyl derivative of cyclic 9-(S)-(3-hydroxyl-2-phosphonomethoxypropyl)adenine, an intravitreally injectable anti-HCMV drug in rabbit and guinea pig. J Ocul Pharmacol Ther 2007;23:433-444.

54 Blumenkranz M, Hernandez E, Ophir A, Norton EW: 5-Fluorouracil: new applications in complicated retinal detachment for an established antimetabolite. Ophthalmology 1984;91:122-130.

-55 Kummar S, Gutierrez M, Doroshow JH, Murgo AJ: Drug development in oncology: classical cytotoxics and molecularly targeted agents. Br J Clin Pharmacol 2006;62:15-26. 
56 Peyman GA, Greenberg D, Fishman GA, Fiscella R, Thomas A: Evaluation of toxicity of intravitreal antineoplastic drugs. Ophthalmic Surg 1984;15:411-413.

57 Yoshizumi MO, Silverman C: Experimental intravitreal 5-fluorocytosine. Ann Ophthalmol 1985;17:58-61.

58 Barrada A, Peyman GA, Case J, Fishman G, Thomas A, Fiscella R: Evaluation of intravitreal 5-fluorouracil, vincristine, VP 16, doxorubicin, and thiotepa in primate eyes. Ophthalmic Surg 1984;15:767-769.

- 59 Leon JA, Britt JM, Hopp RH, Mills RP, Milam AH: Effects of fluorouracil and fluorouridine on protein synthesis in rabbit retina. Invest Ophthalmol Vis Sci 1990;31:1709_ 1716.

60 Kivilcim M, Kazi AA, Peyman GA, Hegazy H, El Dessouky S, Cheema R, Laghari NA: Retinal toxicity of intravitreal 5-fluorouracil in silicone-filled rabbit eyes. J Coll Physicians Surg Pak 2006;16:351-354.

-61 Cardillo JA, Farah ME, Mitre J, Morales PH, Costa RA, Melo LA, Kuppermann B, Jorge R, Ashton P: An intravitreal biodegradable sustained release naproxen and 5-fluorouracil system for the treatment of experimental post-traumatic proliferative vitreoretinopathy. Br J Ophthalmol 2004;88:1201-1205.

-62 Joondeph BC, Peyman GA, Khoobehi B, Yue BY: Liposome-encapsulated 5-fluorouracil in the treatment of proliferative vitreoretinopathy. Ophthalmic Surg 1988;19:252256.

63 Macky TA, Oelkers C, Rix U, Heredia ML, Kunzel E, Wimberly M, Rohrer B, Crosson CE, Rohr J: Synthesis, pharmacokinetics, efficacy, and rat retinal toxicity of a novel mitomycin C-triamcinolone acetonide conjugate. J Med Chem 2002;45:1122-1127.

-64 Kawashima S, Mizota A, Adachi-Usami E, Kimura T: Effects of mitomycin $\mathrm{C}$ on the rat retina. Doc Ophthalmol 1996;92:229-241.

65 Velez G, Yuan P, Sung C, Tansey G, Reed GF, Chan CC, Nussenblatt RB, Robinson MR: Pharmacokinetics and toxicity of intravitreal chemotherapy for primary intraocular lymphoma. Arch Ophthalmol 2001;119: 1518-1524.

66 Yu HG, Chung H: Antiproliferative effect of mitomycin $\mathrm{C}$ on experimental proliferative vitreoretinopathy in rabbits. Korean J Ophthalmol 1997;11:98-105.

67 Huna R, Moisseiev J, Dany S, Ezra D: Lack of intravitreal penetration of colchicine after oral administration in rabbits. Retina 1996; 16:259-261.

68 Davidson C, Green WR, Wong VG: Retinal atrophy induced by intravitreous colchicine. Invest Ophthalmol Vis Sci 1983;24:301-311.

- 69 Fishburne BC, Wilson DJ, Rosenbaum JT, Neuwelt EA: Intravitreal methotrexate as an adjunctive treatment of intraocular lymphoma. Arch Ophthalmol 1997;115:1152-1156.
70 Smith JR, Rosenbaum JT, Wilson DJ, Doolittle ND, Siegal T, Neuwelt EA, Pe'er J: Role of intravitreal methotrexate in the management of primary central nervous system lymphoma with ocular involvement. Ophthalmology 2002;109:1709-1716.

-71 Vernot J, Peyman GA, Gailitis R, Fiscella R, Woodhouse M, Weinberg D: Effects of selected repeated intravitreal chemotherapeutic agents. Int Ophthalmol 1985;8:193-198.

-72 Sou R, Ohguro N, Maeda T, Saishin Y, Tano Y: Treatment of primary intraocular lymphoma with intravitreal methotrexate. Jpn J Ophthalmol 2008;52:167-174.

73 Hardwig PW, Pulido JS, Erie JC, Baratz KH, Buettner H: Intraocular methotrexate in ocular diseases other than primary central nervous system lymphoma. Am J Ophthalmol 2006;142:883-885.

74 Cai J, Wei R, Ma X, Zhu H, Li Y: Cytotoxic effects of antiproliferative agents on human retinal glial cells in vitro. Int Ophthalmol 2001;24:225-231.

75 Hardwig PW, Pulido JS, Bakri SJ: The safety of intraocular methotrexate in silicone-filled eyes. Retina 2008;28:1082-1086.

76 Ueda M, Tanabe J, Inomata M, Kaneko A, Kimura T: Study on conservative treatment of retinoblastoma - effect of intravitreal injection of melphalan on the rabbit retina. Nippon Ganka Gakkai Zasshi 1995;99:12301235.

77 Yamane T, Kaneko A, Mohri M: The technique of ophthalmic arterial infusion therapy for patients with intraocular retinoblastoma. Int J Clin Oncol 2004;9:69-73.

78 Shimoda Y, Hamano R, Ishihara K, Shimoda N, Hagimura N, Akiyama H, Kishi S, Kaneko A: Effects of intraocular irrigation with melphalan on rabbit retinas during vitrectomy. Graefes Arch Clin Exp Ophthalmol 2008; 246:501-508.

79 Kaneko A, Suzuki S: Eye-preservation treatment of retinoblastoma with vitreous seeding. Jpn J Clin Oncol 2003;33:601-607.

80 Abramson DH, Dunkel IJ, Brodie SE, Kim JW, Gobin YP: A phase I/II study of direct intraarterial (ophthalmic artery) chemotherapy with melphalan for intraocular retinoblastoma: initial results. Ophthalmology 2008;115:1398-1404.

81 Iriyama A, Chen YN, Tamaki Y, Yanagi Y: Effect of anti-VEGF antibody on retinal ganglion cells in rats. Br J Ophthalmol 2007;91: 1230-1233.

82 Luke M, Warga M, Ziemssen F, Gelisken F, Grisanti S, Schneider T, Luke C, Partsch M, Bartz-Schmidt KU, Szurman P: Effects of bevacizumab on retinal function in isolated vertebrate retina. Br J Ophthalmol 2006;90: $1178-1182$.
83 Luthra S, Narayanan R, Marques LE, Chwa M, Kim DW, Dong J, Seigel GM, Neekhra A, Gramajo AL, Brown DJ, Kenney MC, Kuppermann BD: Evaluation of in vitro effects of bevacizumab (Avastin) on retinal pigment epithelial, neurosensory retinal, and microvascular endothelial cells. Retina 2006;26: 512-518.

84 Bakri SJ, Cameron JD, McCannel CA, Pulido JS, Marler RJ: Absence of histologic retinal toxicity of intravitreal bevacizumab in a rabbit model. Am J Ophthalmol 2006;142:162164.

85 Heiduschka P, Fietz H, Hofmeister S, Schultheiss S, Mack AF, Peters S, Ziemssen F, Niggemann B, Julien S, Bartz-Schmidt KU, Schraermeyer U: Penetration of bevacizumab through the retina after intravitreal injection in the monkey. Invest Ophthalmol Vis Sci 2007;48:2814-2823.

86 Kaempf S, Johnen S, Salz AK, Weinberger AW, Walter P, Thumann G: Effects of bevacizumab (Avastin) on retinal cells in organotypic culture. Invest Ophthalmol Vis Sci 2008;49:3164-3171.

87 Inan UU, Avci B, Kusbeci T, Kaderli B, Avci R, Temel SG: Preclinical safety evaluation of intravitreal injection of full-length humanized vascular endothelial growth factor antibody in rabbit eyes. Invest Ophthalmol Vis Sci 2007;48:1773-1781.

88 Manzano RP, Peyman GA, Khan P, Kivilcim $\mathrm{M}$ : Testing intravitreal toxicity of bevacizumab (Avastin). Retina 2006;26:257-261.

89 Shahar J, Avery RL, Heilweil G, Barak A, Zemel E, Lewis GP, Johnson PT, Fisher SK, Perlman I, Loewenstein A: Electrophysiologic and retinal penetration studies following intravitreal injection of bevacizumab (Avastin). Retina 2006;26:262-269.

90 Gaudreault J, Fei D, Rusit J, Suboc P, Shiu V: Preclinical pharmacokinetics of ranibizumab (rhuFabV2) after a single intravitreal administration. Invest Ophthalmol Vis Sci 2005;46:726-733

91 Peters S, Heiduschka P, Julien S, Ziemssen F, Fietz H, Bartz-Schmidt KU, Schraermeyer $\mathrm{U}$ : Ultrastructural findings in the primate eye after intravitreal injection of bevacizumab. Am J Ophthalmol 2007;143:995-1002.

-92 Chan CK, Lin SG: Retinal pigment epithelial tear after ranibizumab therapy for subfoveal fibrovascular pigment epithelial detachment. Eur J Ophthalmol 2007;17:674-676.

-93 Rodrigues EB, Shiroma H, Meyer CH, Maia M, Farah ME: Metrorrhagia after intravitreal injection of bevacizumab. Acta Ophthalmol Scand 2007;85:915-916.

94 Rosenfeld PJ, Schwartz SD, Blumenkranz MS, Miller JW, Haller JA, Reimann JD, Greene WL, Shams N: Maximum tolerated dose of a humanized anti-vascular endothelial growth factor antibody fragment for treating neovascular age-related macular degeneration. Ophthalmology 2005;112:10481053. 
95 Rosenfeld PJ: Intravitreal Avastin: the low cost alternative to Lucentis? Am J Ophthalmol 2006;142:141-143.

96 Rosenfeld PJ: New treatments for age-related macular degeneration. Lancet 2007;370: 1479, author reply 1480 .

$\checkmark 97$ Dick AD, Forrester JV, Liversidge J, Cope AP: The role of tumour necrosis factor (TNF-alpha) in experimental autoimmune uveoretinitis (EAU). Prog Retin Eye Res 2004;23:617-637.

-98 Imrie FR, Dick AD: Biologics in the treatment of uveitis. Curr Opin Ophthalmol 2007; 18:481-486.

99 Giansanti F, Ramazzotti M, Vannozzi L, Rapizzi E, Fiore T, Iaccheri B, Degl'Innocenti D, Moncini D, Menchini U: A pilot study on ocular safety of intravitreal infliximab in a rabbit model. Invest Ophthalmol Vis Sci 2008;49:1151-1156.

$\checkmark 100$ Fauser S, Kalbacher H, Alteheld N, Koizumi K, Krohne TU, Joussen AM: Pharmacokinetics and safety of intravitreally delivered etanercept. Graefes Arch Clin Exp Ophthalmol 2004;242:582-586.

-101 Kivilcim M, Peyman GA, Kazi AA, Dellacroce J, Ghobrial RN, Monzano R: Intravitreal toxicity of high-dose etanercept. J Ocul Pharmacol Ther 2007;23:57-62.

- 102 Manzano RP, Peyman GA, Carvounis PE, Kivilcim M, Khan P, Chevez-Barrios P, Takahashi W: Ocular toxicity of intravitreous adalimumab (Humira) in the rabbit. Graefes Arch Clin Exp Ophthalmol 2008; 246:907-911.

103 Lim L, Suhler EB, Smith JR: Biologic therapies for inflammatory eye disease. Clin Exp Ophthalmol 2006;34:365-374.

104 Suhler EB, Smith JR, Wertheim MS, Lauer AK, Kurz DE, Pickard TD, Rosenbaum JT: A prospective trial of infliximab therapy for refractory uveitis: preliminary safety and efficacy outcomes. Arch Ophthalmol 2005; 123:903-912.

105 Theodossiadis PG, Markomichelakis NN, Sfikakis PP: Tumor necrosis factor antagonists: preliminary evidence for an emerging approach in the treatment of ocular inflammation. Retina 2007;27:399-413.

106 Coiffier B: Rituximab therapy in malignant lymphoma. Oncogene 2007;26:3603-3613.

$\checkmark 107$ Kim H, Csaky KG, Chan CC, Bungay PM, Lutz RJ, Dedrick RL, Yuan P, Rosenberg J, Grillo-Lopez AJ, Wilson WH, Robinson MR: The pharmacokinetics of rituximab following an intravitreal injection. Exp Eye Res 2006;82:760-766

108 Kitzmann AS, Pulido JS, Mohney BG, Baratz KH, Grube T, Marler RJ, Donaldson MJ, O’Neill BP, Johnston PB, Johnson KM, Dixon LE, Salomao DR, Cameron JD: Intraocular use of rituximab. Eye 2007;21: 1524-1527.
109 Kim SJ, Adams NA, Toma HS, Belair ML, Thorne JE, Green WR, Jabs DA: Safety of intravitreal ketorolac and diclofenac: an electroretinographic and histopathologic study. Retina 2008;28:595-605.

110 Komarowska I, Heilweil G, Rosenfeld PJ, Perlman I, Loewenstein A: Retinal toxicity of commercially available intravitreal ketorolac in albino rabbits. Retina 2009;29: 98-105.

111 Morales AM, Kivilcim M, Peyman GA, Main M, Manzano RP: Intravitreal toxicity of ketorolac Tris salt and flurbiprofen. Ophthalmic Surg Lasers Imaging 2009;40: 38-42.

112 Trese MT: Enzymatic-assisted vitrectomy Eye 2002;16:365-368.

113 Textorius O, Stenkula S: Toxic ocular effects of two fibrinolytic drugs: an experimental electroretinographic study on albino rabbits. Acta Ophthalmol (Copenh) 1983;61:322-331

114 De Smet MD, Valmaggia C, Zarranz-Ventura J, Willekens B: Microplasmin: ex vivo characterization of its activity in porcine vitreous. Invest Ophthalmol Vis Sci 2009 50:814-819

115 Wang ZL, Shi WD, Luo M, Bi XP, Ji J: Pharmacologic vitreolysis with plasmin and hyaluronidase in diabetic rats. Retina 2009; 29:269-274.

116 Frenkel S, Hendler K, Siegal T, Shalom E, Pe'er J: Intravitreal methotrexate for treating vitreoretinal lymphoma: 10 years of experience. Br J Ophthalmol 2008;92:383388.

117 Srinivasan K, Ramarao P: Animal models in type 2 diabetes research: an overview. Indian J Med Res 2007;125:451-472.

118 Danis RP, Ciulla TA, Pratt LM, Anliker W Intravitreal triamcinolone acetonide in exudative age-related macular degeneration. Retina 2000;20:244-250.

119 Jonas JB, Kreissig I, Degenring RF: Intravitreal triamcinolone acetonide as treatment of ischemic ophthalmopathy. Eur J Ophthalmol 2003;13:575-576.

120 Jonas JB, Kreissig I, Degenring RF: Intravitreal triamcinolone acetonide for pseudophakic cystoid macular edema. Am J Ophthalmol 2003;136:384-386.

121 Jonas JB, Kreissig I, Degenring RF: Retinal complications of intravitreal injections of triamcinolone acetonide. Graefes Arch Clin Exp Ophthalmol 2004;242:184-185.

122 Ranson NT, Danis RP, Ciulla TA, Pratt L: Intravitreal triamcinolone in subfoveal recurrence of choroidal neovascularisation after laser treatment in macular degeneration. Br J Ophthalmol 2002;86:527-529.

123 Avci R, Kaderli B: Intravitreal triamcinolone injection for chronic diabetic macular oedema with severe hard exudates. Graefes Arch Clin Exp Ophthalmol 2006;244:2835.
124 Gibran SK, Cullinane A, Jungkim S, Cleary PE: Intravitreal triamcinolone for diffuse diabetic macular oedema. Eye 2006;20: $720-724$.

125 Jonas JB, Hayler JK, Sofker A, Panda-Jonas $\mathrm{S}$ : Intravitreal injection of crystalline cortisone as adjunctive treatment of proliferative diabetic retinopathy. Am J Ophthalmol 2001;131:468-471.

126 Williamson TH, O’Donnell A: Intravitreal triamcinolone acetonide for cystoid macular edema in nonischemic central retinal vein occlusion. Am J Ophthalmol 2005; 139 : 860-866.

127 Lee H, Shah GK: Intravitreal triamcinolone as primary treatment of cystoid macular edema secondary to branch retinal vein occlusion. Retina 2005;25:551-555.

128 Wang K, Jiang YR, Li XX: Vehicle of triamcinolone acetonide is associated with retinal toxicity and transient increase of lens density. Graefes Arch Clin Exp Ophthalmol 2006;244:1152-1159.

129 Lang Y, Leibu R, Shoham N, Miller B, Perlman I: Evaluation of intravitreal Kenalog toxicity in humans. Ophthalmology 2007; 114:724-731.

130 Li Q, Wang J, Yang L, Mo B, Zeng H, Wang N, Liu W: A morphologic study of retinal toxicity induced by triamcinolone acetonide vehicles in rabbit eyes. Retina 2008;28: 504-510.

131 Macky TA, Helmy D, El Shazly N: Retinal toxicity of triamcinolone's vehicle (benzyl alcohol): an electrophysiologic and electron microscopic study. Graefes Arch Clin Exp Ophthalmol 2007;245:817-824.

132 Rodriguez-Coleman H, Yuan P, Kim H, Gravlin L, Srivastava S, Csaky KG, Robinson MR: Intravitreal injection of triamcinolone for diffuse macular edema. Arch Ophthalmol 2004;122:1085-1086, author reply $1086-1088$.

133 Lang Y, Zemel E, Miller B, Perlman I: Retinal toxicity of intravitreal Kenalog in albino rabbits. Retina 2007;27:778-788.

-134 Li Q, Wang J, Yang L, Mo B, Zeng H, Wang N, Liu W: A morphologic study of retinal toxicity induced by triamcinolone acetonide vehicles in rabbit eyes. Retina 2008;28: 504-510.

135 Loewenstein A, Zemel E, Lazar M, Perlman I: The effects of Depo-Medrol preservative on the rabbit visual system. Invest Ophthalmol Vis Sci 1991;32:3053-3060.

136 Luke M, Januschowski K, Warga M, Beutel J, Leitritz M, Gelisken F, Grisanti S, Schneider T, Luke C, Bartz-Schmidt KU, Szurman P: The retinal tolerance to bevacizumab in co-application with a recombinant tissue plasminogen activator. $\mathrm{Br} \mathrm{J}$ Ophthalmol 2007;91:1077-1082. 
137 Loewenstein A, Zemel E, Lazar M, Perlman I: Drug-induced retinal toxicity in albino rabbits: the effects of imipenem and aztreonam. Invest Ophthalmol Vis Sci 1993;34: 3466-3476.

138 Rowley SA, Vijayasekaran S, Yu PK, McAllister IL, Yu DY: Retinal toxicity of intravitreal tenecteplase in the rabbit. Br J Ophthalmol 2004;88:573-578.

139 Frambach DA, Marmor MF: The rate and route of fluid resorption from the subretinal space of the rabbit. Invest Ophthalmol Vis Sci 1982;22:292-302.

140 Ivert L, Kjeldbye H, Gouras P: Long-term effects of short-term retinal bleb detachments in rabbits. Graefes Arch Clin Exp Ophthalmol 2002;240:232-237.
141 Negi A, Marmor MF: Effects of subretinal and systemic osmolality on the rate of subretinal fluid resorption. Invest Ophthalmol Vis Sci 1984;25:616-620.

-142 Negi A, Marmor MF: Experimental serous retinal detachment and focal pigment epi thelial damage. Arch Ophthalmol 1984; 102:445-449.

$>143$ Negi A, White MP, Marmor MF: Effects of hemicholinium-3, a photoreceptor and pigment epithelial toxin, on retinal adhesiveness and subretinal fluid absorption. Doc Ophthalmol 1993;83:331-336.
144 Ho JD, Tsai RJ, Chen SN, Chen HC: Cytotoxicity of indocyanine green on retinal pigment epithelium: implications for macular hole surgery. Arch Ophthalmol 2003; 121:1423-1429.

145 Ikagawa H, Yoneda M, Iwaki M, Isogai Z, Tsujii K, Yamazaki R, Kamiya T, Zako M: Chemical toxicity of indocyanine green damages retinal pigment epithelium. Invest Ophthalmol Vis Sci 2005;46:25312539.

146 Sippy BD, Engelbrecht NE, Hubbard GB, Moriarty SE, Jiang S, Aaberg TM Jr, Aaberg TM Sr, Grossniklaus HE, Sternberg P Jr: Indocyanine green effect on cultured human retinal pigment epithelial cells: implication for macular hole surgery. Am J Ophthalmol 2001;132:433-435. 